\title{
Yapay Zeka ve Eğitimde Gelecek Senaryoları
}

\author{
DOI: 10.26466/opus.911444
}

\author{
* \\ Münevver Çetin * $-\underline{\text { Abdussamet Aktaș }}$ ** \\ * Prof. Dr., Marmara Üniversitesi, Eğitim Fakültesi, İstanbul/Türkiye \\ E-Posta: mcetin@marmara.edu.tr ORCID: 0000-0002-1203-9098 \\ ** Dr. Öğr., Marmara Üniversitesi, Eğitim Fakültesi, İStanbul/Türkiye \\ E-Posta: abdussametaktas@marun.edu.tr $\quad$ ORCID: $\quad$ 0000-0002-8363-0053
}

Öz

Yapılan çalışmalar neticesinde hızlı gelişim gösteren, edindiği yeni yeteneklerle hayatımızın her alanında daha fazla yer edinmeye devam eden yapay zekanın, edineceği yeni yeteneklerle gelecekte hemen hemen tüm mesleklerde insanı devre dışı bırakmasından endişe edilmektedir. Bu araştırmanın amacı aynı endişeler ışı̆̆ında yapay zekanın eğitimde yer alacă̆ı senaryolar ortaya koyarak bu senaryolar uzman görü̧̧leri doğrultusunda incelemektir. Araştırmada nitel araştırma yöntemi benimsenmiş olup, katılımcıların görüşleri fenomonolojik bir yaklaşımla derinlemesine analiz edilmiştir. Veri toplama aracı olarak, araştırmacılar tarafından hazırlanan yarı yapılandırılmış görüşme soruları kullanılmıştır. Araştırmanın çalışma grubunu, kartopu örnekleme yöntemi ile ulaşılmış Türkiye'de çeşitli üniversitelerde görevli yapay zekâ alanında uzman 10 akademik personel oluşturmaktadır. Görüşmeler neticesinde elde edilen veriler betimsel analiz yöntemi ile çözümlenmiştir. Çözümlemeler doğrultusunda veriler, senaryolarla ilgili olası faydalar, endişeler ve uygulanabilirlik alt temaları altında toplanmıştır. Bulgulara göre yapay zekânın öğretmenin yerini aldığl ve okul yönetiminde müdür rolünü aldığ̀ senaryolarda birçok fayda sağlanacaktır. Bulgulara göre bu senaryolar aynı zamanda birçok endişeyi beraberinde getirmektedir. Araştırmanın bir diğer bulgusuna göre yapay zekâ günümüzdeki mevcut yetenekleriyle öğretmenin ya da okul müdürünün yerini alamayacaktır ve gerekli gelişimler sağlanmadı̆̆̊ sürece öğretmenin ve okul müdürünün asistanı rolünde kalması daha faydalı olacaktır.

Anahtar Kelimeler: Eğitim, yapay zeka, öğretmen, okul müdürü, gelecek senaryoları. 


\title{
Artificial Intelligence and Future Scenarios in Education
}

*

\begin{abstract}
It is feared that artificial intelligence, which develops rapidly as a result of the studies and continues to gain more place in all areas of our lives with its new abilities, will disable people in almost all professions in the future with the new abilities it will acquire. The aim of this research is to reveal scenarios in which artificial intelligence will take place in education in the light of the same concerns and examine these scenarios in line with expert opinions. In the research, qualitative research method was adopted and the opinions of the participants were analyzed in depth with a phenomenological approach. As a data collection tool, semi-structured interview questions prepared by the researchers were used. The study group of the research consists of 10 academic staff who are experts in the field of artificial intelligence, working at various universities in Turkey, reached by snowball sampling method. The data obtained as a result of the interviews were analyzed by descriptive analysis method. In line with the analysis, the data were gathered under the sub-themes of possible benefits, concerns and applicability related to the scenarios. According to the findings, many benefits will be provided in scenarios where artificial intelligence replaces the teacher and takes the role of principal in school management. According to the findings, these scenarios also raise many concerns. According to another finding of the research, artificial intelligence will not be able to replace the teacher or school principal with its current abilities, and it will be more beneficial for the teacher and the school principal to remain in the role of assistant unless necessary developments are made.
\end{abstract}

Keywords: Education, artificial intelligence, teacher, principal, future scenarios. 


\section{Giriş}

İnsan dünyadaki tüm canlılar arasında en zeki olacak şekilde yaratılmıştır. Bu özelliğini; düşünme, öğrenme, akıl yürütme, olayları algılama, anlam çıkartma, sonuca ulaşma, duruma göre karar verme anlamlarına gelen "zekâ" (Türk Dil Kurumu, 2020) ile donatılmış olmasına borçludur. Bilgisayarın icadı ile birlikte insani bir özellik olan zekâ ile ilgili yeteneklerin makineler tarafından da yapılabileceği keşfedilmiştir. $\mathrm{Bu}$ keşiften itibaren makinelerin kendi kendine düşünebilmesi, karar verebilmesi, öğrenebilmesi ve hatta yönetebilmesi için çalışmalar devam etmektedir.

Yapay zeka insan bilişini algılayabilen, akıl yürütebilen, kavrayabilen, anlamlandırabilen, genelleştirebilen, çıkarımda bulunabilen, öğrenebilen, aynı anda birden fazla işi başarıyla gerçekleştirebilen (Gondal, 2018, s.1), bir anlamda insan zekasını taklit edebilen bilişim teknolojisidir. Yapay zekâ aynı zamanda insan zekâsını ve beynin çalışma sistemini inceleyerek gelişimini sürdürmeye devam etmekte olan bir bilim dalıdır. Teng'e (2019) göre halen insan zekâsı yapay zekâdan daha üstündür fakat ortamın hızlı değişim göstermesi, görevlerin karmaşıklığı, belirli sırayla ve değişmeyen yöntemle aynı anda birçok işin çözümlenmesi söz konusu olduğunda yapay zekâ insan beynine göre çok daha hızlı çalışabilmektedir.

Genel olarak makineler tarafından gösterilen zekâ olarak tanımlanan yapay zekâ, karmaşık sorunların çözümlenmesinde ve değişen koşulların dikkate alınarak karar verilmesinde insan zekâsının özellikleri olan muhakeme etme ve tahmin gücünün makineler tarafından kullanılmasını ifade etmektedir (Obschonka ve Audretsch, 2020, s.530). Yapay zekâ kavramının 1956 yılında McCarthy tarafından telaffuz edilerek isim babalığının üstlenilmesi sonrasında (Ertel, 2011, s.1), yapay zekâ çalışmaları hızlanmıştır. Yapılan çalışmalarla birlikte yapay zeka tanımlamalarında farklılıklar oluşmuş ve oluşan bu tanımlamalar Tablo 1 'de gösterilmiştir.

Tanımlardan da anlaşılacağı üzere yapay zekâ karmaşık işleri insanlardan daha iyi yapma, birden çok probleme odaklanarak çözüme kavuşturma, öğrenme, akıl yürütme gibi yeteneklere sahip hem bir "beyin" hem de bu amaçla çalışmalar yürütülen bir bilim dalıdır. Bu 
bağlamda yapay zekanın; durumu bir uzman olarak ele alıp performans üretme, olası problem çözümleri içerisinden çözüme en yakın tahmini yapma, insan ile doğal dil iletişimini sağlayabilme, şekilleri, yüzleri, özellikleri vb. otomatik olarak tanıma yeteneklerine sahip olduğu ifade edilmektedir (Singh, Mishra ve Sagar, 2013, s.1).

\section{Tablo 1. Yapay Zekâ Tanımlamaları}

İnsan düşüncesi ile ilişkilendirdiğimiz karar verme, problem çözme, öğrenme gibi faaliyetlerin otomasyonu (Bellman, 1978).

Tam ve gerçek anlamda zihinleri olan makineler (Haugeland, 1985).

Sayısal modellerin kullanılması yoluyla zihinsel becerilerin incelenmesi (Charniak ve McDermott, 1985).

İnsanlar tarafından yapıldığında zekâ gerektiren işlevleri yerine getiren makineler yaratma sanatı (Kurzweil, 1990).

Akıllı davranışı hesaplama süreçleri açısından açıklamayı ve taklit etmeyi amaçlayan bir çalı̧̧ma alanı (Schalkoff, 1990).

Şu anda insanların iyi olduğu şeyleri bilgisayarların nasıl daha iyi yapacağına dair çalışma alanı (Rich and Knight, 1991).

Akıllı davranışın otomasyonu ile ilgilenen bilgisayar bilim dalı (Luger and Stubblefield, 1993).

Kaynak: Russell ve Norvig (1995).

Yapay zekânın gelişiminde son yıllarda gerçekleştirilen önemli adımlardan biri derin öğrenmedir. Derin öğrenme, yapay sinir ağlarının oluşturulması ve bu sayede yapay zekânın veriye dayalı bir şekilde aynı anda çok boyutlu işlem gerçekleştirebilmesi, kendi kendine öğrenme, çıkarım, tahmin yapabilme eylemlerini kendisinin yapabilmesi olarak tanımlanmaktadır (Mathew, Arul ve Sivakumari, 2020, s.1-9). Bunun en iyi örneklerini otonom araçlarda görmek mümkündür.

Gelecek yıllarda da yapay zekânın gelişimi günümüzdekinden çok daha hızlı bir şekilde devam edecektir. Boucher'e göre (2019) gelecekteki yapay zekâ için üç kavram ön plana çıkacaktır. Bunlar; belirli alanlarla sinırlı olmayan yapay genel zekâ, insanlardan daha yüksek zekâ seviyesine sahip yapay zekâyı ifade eden yapay süper zekâ, yapay zekânın daha akıllı ve özerk yapay zekâ üretmesi ve otonom hale gelmesini ifade eden tekilliktir. Bu üç kavramdan yola çıkarak yapay zekânın gelecekte bilişsel anlamda insandan daha üstün olabileceğini belirtmemiz mümkündür.

Yapay zekâ günümüzde iletişim, iş ve işlemlerin dijital ortamda gerçekleştirilmesi, konum bulma, bilgiye hızla ulaşma, eğlence, depolama, bankacılık, finans, sosyal medya, sağlık, kurum ve ülke güvenliğini sağlama gibi neredeyse hayatımızın her alanında 
kullanılmaktadır (Komalavalli, Hemalatha ve Dhanalakshimi, 2020, s.9091). Ayırt etme yeteneği ile sahneye çıkan yapay zekâ yapılan çalışmalar neticesinde artık algılama, kendi kendine öğrenme ve karar verme, çıkarımda bulunma gibi özellikleri ile hayatımıza yön vermektedir. Yakın gelecekte ise yapay zekânın, birçok işi üstlenerek insanlığın hayatını kolaylaştıracağı ve günlük hayatta insandan daha fazla rol alacağ 1 beklenmektedir.

$\mathrm{Bu}$ durum bazı endişeleri de beraberinde getirmektetir. $\mathrm{Bu}$ endişelerden bazıları; yapay zekanın hayatın her alanında yer almasıyla birlikte toplayacağı verilerin akıbeti, bu verilere erişim imkânı olanların kimler olduğu, toplanan veriler üzerinde ne tür işlemler yapılacağ 1 ve verilerin satılması gibi konulardır (Oliveira, Lopes, Soares, Pinheiro ve Guimaraes, 2020, s.1-3). Özellikle bireylerin artık teknolojiyi daha fazla kullandığ1 ve dijital ortamda daha fazla vakit geçirdiği düşünülürse elde edilen veri miktarı tahmin edilebilir ve bu endişe yerinde bulunabilir. Fast ve Horvitz'e göre (2017) yapay zekâ ile ilgili diğer endişeler; kontrolden çıkması, savaşlarda insan kaybının artması, insanların işsiz kalması şeklindedir. Bu endişeler arasında yapay zekânın tüm meslek dallarında insanların yerini alabilecek olması günümüzde üzerinde en fazla tartışılan alandir.

\section{Eğitimde Yapay Zekâ}

Yapay zekânın eğitime entegrasyonu diğer alanlarla karşılaştırıldığında henüz düşük seviyededir. Fakat alandaki gelişimin hızı düşünülürse yakın gelecekte eğitimi oluşturan ana paydaşları etkilemesi beklenmektedir. Bu etkilenmenin paydaşlara avantajlar sağlayabileceği gibi beraberinde dezavantajlarda getirmesi muhtemeldir. Bu bağlamda yapay zekânın eğitimin dört ana paydaşı olarak; eğitim örgütü, öğretmen, öğrenci ve veli tarafından kullanılması durumunda sağlayacağı avantajlar ve getireceği dezavantajlar Tablo 2' de gösterilmiştir.

Eğitim bağlamında günümüz yapay zekâ çalışmaları incelendiğinde eğitim örgütü, veli, öğretmen ve öğrenci arasında en fazla gelişme sağlanan ve üzerinde çalışma yapılan alanın öğrenci ve öğrenme üzerine olduğu görülmektedir. 
Tablo 2. Yapay Zekanın Ĕ̆itim Paydaşları Bağlamında Avantaj ve Dezavantajları

\begin{tabular}{|c|c|c|}
\hline Paydaş & Avantaj & Dezavantaj \\
\hline $\begin{array}{l}\text { Eğitim } \\
\text { Örgütü }\end{array}$ & $\begin{array}{l}\text { Öğrencilerin kişilik ve birey olarak } \\
\text { tespiti, Okul güvenliği, Değerlendirme } \\
\text { nesnelliği, Dijital öğrenme, Öğrenci } \\
\text { kişisel verilerinin korunması, Verimli } \\
\text { öğrenme ve ders çalışma imkânı, Hayat } \\
\text { boyu öğrenme, Kişiselleştirilmiş öğretim. }\end{array}$ & $\begin{array}{l}\text { Yeni sisteme duyulan düşük güven, } \\
\text { Öğrencilerin yaratıcı çalışmalarını } \\
\text { değerlendirme aşamasında yaşanması } \\
\text { muhtemel sorunlar, Sınıf disiplininin } \\
\text { sağlanması noktasında var olan } \\
\text { endişeler, Sistemin çökme ya da } \\
\text { saldırıya uğrama ihtimali. }\end{array}$ \\
\hline Öğrenci & $\begin{array}{l}\text { Öğrenme sürecini nesnel bir gözden } \\
\text { izleyebilme, Uzaktan öğrenmede kalite } \\
\text { artışı, Yeni teknolojilere entegre olma, } \\
\text { Her an erişebilirlik. }\end{array}$ & $\begin{array}{l}\text { Motive olmada zorlanma, } \\
\text { Ö̈̆grenci öğretmen iletişim ve etkileşim } \\
\text { eksikliği. }\end{array}$ \\
\hline Öğretmen & $\begin{array}{l}\text { Öğrencileri yönetmede kolaylık, Görev } \\
\text { ve içerik oluşturmanın otomatikleşmesi, } \\
\text { Sürekli iyileştirme, Nesnel } \\
\text { değerlendirme, Hızlı ve eksiksiz geri } \\
\text { bildirim, Performans takibi, } \\
\text { Öğretmenlerin güçlü yönlerinin } \\
\text { korunması, Zayıf yönlerinin gelişimine } \\
\text { katkı sağlanması. }\end{array}$ & $\begin{array}{l}\text { Öğretmenden beklenen mesleki } \\
\text { yeterliliklerin yükselmesine neden } \\
\text { olabilir, } \\
\text { Öğretmenlerin yerini alabilir. }\end{array}$ \\
\hline Veli & $\begin{array}{l}\text { Gerçek zamanlı geri bildirim, İlerlemeler } \\
\text { hakkında bilgilendirme, Öğrencileri için } \\
\text { yeni öğrenme fırsatları, Maddi durumu } \\
\text { yetersiz ailelerin eğitime ulaşmasında } \\
\text { sorunların azaltılması. }\end{array}$ & $\begin{array}{l}\text { İnsanlarla iletişim kurulmadığı için } \\
\text { iletişim ve etkileşim eksikliği ile } \\
\text { beraber insandışılaşma. }\end{array}$ \\
\hline
\end{tabular}

Kaynak: Osetskyi, Vitrenko, Tatomyr, Bilan ve Hirnyk. (2020).

Kişiselleştirilmiş öğretim ve öğretim asistanı, standardize edilmiş müfredat ve tüm öğrenciler için tek tip gerçekleştirilen öğretim yöntemlerinin çeşitlendirilmesi gibi açılardan sunduğu fırsatlar bu alana öncelik verilmesinin nedenleri olarak sayılabilir. Bu öncelik neticesinde öğrencileri analiz ederek duygu ve öğrenme yöntemi tespiti yapan uygulamalar, sanal etkileşimli öğretmenler, kişiselleştirilmiş öğrenme sistemleri, akıllı eğitim sistemleri gibi yapay zekâ temelli sistemler geliştirilerek hem öğretimin bireyselleştirilmesi sağlanmakta hem de veriye dayalı öğretim ve rehberlik yapılabilmektedir. Örneğin; Carnegie Learning (U.S Department of Education, 2013, s.1), Jill Watson (Goel ve Polepeddi, 2016, s.5-6), EBA ADES (MEB, 2020), iTalk2Learn (Grawemeyer vd., 2017, s.6) gibi uygulama ve platformları yapay zeka tabanlı hizmet veren akıllı eğitim sistemleridir.

Eğitimde yapay zekâ çalışmaları sadece öğrenmenin etkililiği ile sınırlı kalmamakta eğitimin diğer alanlarında da aktif kullanılmasına yönelik 
çalışmalar devam etmektedir. Bu kapsamda üzerinde geliştirme çalışmaları devam eden alanlar ve bu alanlarda uygulanması hedeflenen teknikler Tablo 3'te gösterilmiştir.

Tablo 3. Eğitimde Yapay Zeka Uygulama Alanları ve Teknikleri

\begin{tabular}{ll}
\hline Yapay Zeka Uygulama Alanı & Teknikler \\
\hline $\begin{array}{l}\text { Öğrencinin ve okulların } \\
\text { değerlendirilmesi }\end{array}$ & $\begin{array}{l}\text { Adaptif öğrenme yöntemi, Kişiselleştirilmiş öğrenme } \\
\text { yaklaşımları, Akademik analizler }\end{array}$ \\
\hline $\begin{array}{l}\text { Ödev ve sınavların } \\
\text { derecelendirilmesi, } \\
\text { değerlendirilmesi }\end{array}$ & Görüntü analizi, Bilgisayar görüşü, Tahmin sistemi \\
\hline Kişiselleştirilmiş akıllı öğretim & $\begin{array}{l}\text { Veri madenciliği, Bilgi müdahalesi, Bireyin ve } \\
\text { öğrenmenin analizi }\end{array}$ \\
\hline Akıllı okul & $\begin{array}{l}\text { Yüz tanıma ve ses tanıma, Akıllı laboratuvarlar, AR, } \\
\text { VR sistemleri, İşitme algılama teknolojileri }\end{array}$ \\
\hline Çevrimiçi ve uzaktan mobil eğitim & $\begin{array}{l}\text { Bireyin hassas analizi, Sanal kişiselleştirilmiş } \\
\text { asistanlar, Gerçek zamanlı analiz ve anlık geri bildirim }\end{array}$ \\
\hline
\end{tabular}

Kaynak: Chen, Chen ve Lin (2020).

Yapılan çalışmalar eğitimde; not verme ve değerlendirme, öğrencilerin devamsızlık ve okul terk tahmini, öğrenci performans tahmini, kişiselleştirilmiş öğretim, duygu analizi, öneri sistemleri, akıllı eğitim sistemleri, sınıf izleme, akıllı okul, okul değerlendirme ve yönetimi, denetleme ve analiz sistemleri şeklinde devam etmektedir (Ahmad vd., 2020, s.8; Chen vd., 2020, s.75272). Diğer taraftan ses ve yüz tanıma sistemleri ile veri toplanması, dersler, konular ve değerlendirmeler üzerinden eğitim profillerinin oluşturulması, 3B ve hologram öğrenme ortamları, VR teknolojisinin eğitime dâhil edilmesi, öğretmen yerine yapay zekâ istihdamı gibi gelişmeler bizleri beklemektedir (Taneri, 2020, s.6). Buradan hareketle yakın gelecekte yapay zekanın kendini sinıf yönetiminde ve okul yönetiminde daha fazla göstermesini beklememiz mümkündür.

\section{Eğitimde Gelecek Senaryoları}

Örgütler ve devletler tarafından sık kullanılan gelecek senaryoları geleneksel araştırma metodolojilerinin aksine, algıların çeşitliliğini kabul ederek olası geleceği hayal etmeyi amaçlayan disiplinli bir yöntemdir (Yeoman vd., 2015, s.117). Geleceğin bilinmezliklerini en aza indirmek ve 
öngörülebilir bir gelecek oluşturmayı amaçlayan zihinsel kurguları ifade eden gelecek senaryoları sayesinde geleceğin nasıl şekilleneceği ve geleceğe ne şekilde hazırlanmak gerektiği belirlenmektedir (Aşçı, 2017, s.379). Dolayısıyla stratejik düşünmede bir araç olarak görülen gelecek senaryolarını, şu an bildiklerimizden yola çıkarak geleceğe dair bilmediklerimizin kurgulanması şeklinde ifade etmek mümkündür.

Senaryo oluşturma geleceğe bakış açısına göre prospektif ve projektif senaryolar şeklinde sınıflandırılmaktadır. Prospektif senaryoda başlangıç noktası şimdiki zamandır, alternatif gelecek seçenekleri vardır. Projektif senaryoda ise gelecek apaçık ortada kabul edilerek şimdiden o geleceğin gerçekleşmesi adına eylem ve stratejiler üretilmektedir (Wieringen, Sellin ve Schmidt, 2003, s.28).

Araştırma, günümüzde yapay zekanın geldiği noktayı ve kullanım alanlarını göz önüne alarak gelecekte eğitimin olası prospektif senaryolarını ortaya koymayı amaçlamaktadır. Bu bağlamda oluşturulan senaryolar aşağıda özetlenmiştir:

\section{Senaryo 1: Sınıf Yönetiminde Yapay Zekâ:}

Bu senaryoda öğretmenlik mesleği, diğer meslekler için öngörüldüğü gibi yerini yapay zekâya bırakmaktadır. Bu durumda; öğrenciler ve velilerle ilişkiler, ölçme değerlendirme uygulamaları, öğrenci devamsızlığı, müfredat ve ders planı hazırlanması gibi beceriler gerektiren sinıf yönetiminde yapay zekânın olası faydaları, senaryo dâhilinde oluşacak endişeler ve senaryonun uygulanabilirliği sorgulanacaktır.

\section{Senaryo 2: Okul Yönetiminde Yapay Zekâ:}

$\mathrm{Bu}$ senaryoda yapay zekâ okul müdürünün yerine geçerek okul yönetiminde görev alacaktır. Bu durumda; yapay zekânın, okul güvenliği, akademik başarı, mali yönetim, veliler ve öğretmenlerle iletişim gibi okul yönetim becerileri temelinde günümüz yöneticilerinden farkı, olası faydaları, senaryo dâhilinde oluşacak endişeler ve senaryonun uygulanabilirliği sorgulanacaktır.

Ayrıca senaryolar çerçevesinde yapay zekânın öğretmenin ya da okul müdürünün yerini alıp alamayacağı tartışılacak, katılımcıların görüşleri 
doğrultusunda yapay zekânın sınıf ve okul yönetiminde muhtemel konumu belirlenmeye çalışılacaktır.

$\mathrm{Bu}$ iki senaryo doğrultusunda öncelike günümüzde yaşanan gelişmelere ve senaryo kapsamında yapılmış araştırmalara odaklanılacaktır. Bu kapsamda gelecek senaryolarının detaylı içeriği aşağıdaki gibidir:

\section{Senaryo 1: Sınıf Yönetiminde Yapay Zeka}

Sınıf yönetimi, öğrencilerde öğrenmenin sağlanması, sınıf disiplini, öğrenci rehberliği, öğrencilerin sosyal, kültürel, ahlaki gelişiminin sağlanması, öğrenci ve velilerle etkileşim, ölçme değerlendirme uygulamaları, ders planları hazırlama gibi öğretmenlik becerileri gerektirmektedir (Chandra, 2015, s.14). Günümüzde bu olguyu yerine getirmek öğretmenlerin görevidir fakat diğer meslekler için öngörüldüğü gibi gelecekte öğretmenin yerini de yapay zekânın alması muhtemeldir. Bu bağlamda Senaryo 1 öğretmenin yerini yapay zekâ sisteminin alması üzerine kurulmuştur.

Günümüzde çoğunlukla akıllı öğretim sistemleri aracılığıyla eğitime dâhil edilen yapay zekâya insani özellikler kazandırılması ile birlikte sosyal iletişim ve etkileşim gerektiren mesleklerde insanın yerini alması kaçınılmaz olacaktır. Eğitim öğretimin merkezinde yer alan öğretmen yerine yapay zekânın kullanımı, mevcut yeteneklerinden hareketle değerlendirildiğinde; uyarlanabilirlik, bireyselleştirme, nitelikli karar verme, öğrencilerin öğrenme yöntemlerini, kavrama kabiliyetlerini ve konunun öğrenilme durumunu hizlıca tespit etme, öğrencilerin derse ve etkinliklere katılımı, insani duyguların sınıf yönetimine karışmaması gibi açılardan faydalar sağlayacağı düşünülmektedir. Diğer taraftan Edwards ve Cheok'a (2018) göre yapay zekânın öğretimsel sunum, kişilik, pedagojik yaklaşım, hareket sistemi ve duygusal alanlardaki gelişimini tamamlaması halinde bir diğer faydası ülkelerin öğretmen eksikliğini gidermesi şeklinde olacaktır.

Senaryo 1 bağlamında, ilgili alan yazın incelendiğinde yapay zekânın öğretmenin yerini alamayacağını sebeplendiren ve alması durumunda hangi endişelerin bizi beklediğine değinen çalışmaların çoğunlukta 
olduğu görülmektedir. Bu kapsamda araştırmaya temel sağlayacak bu çalışmalardan bazılarına aşağıda yer verilecektir:

Yapay zekânın öğretmenin yerini alamayacağını ifade eden Kolchenko (2018, s.250), sistemi seven ve zevkle kullanan motive olmuş öğrencilerin sisteme yeterli ve kaliteli veriyi üreteceğini, sistemi kandırmaya yönelik davranışlar sergileyen öğrencilerin kıt veriler üreteceğini ifade etmektedir. Bu bağlamda yapay zekânın yeterli verileri elde edememesi neticesinde kişiselleştirilmiş öğretimde niteliğin düşeceği ifade edilebilir.

Diğer taraftan yapay zekânın henüz pedagojik bağlamdan uzak olduğunu belirten Kolchenko (2018, s.251), öğrenmekten korkan ve kaçınan öğrencilerle başa çıkamayacağını, öğrenci öğretmen etkileşimi neticesinde oluşan şablonların oluşturulmasında yapay zekânın yetersiz kalacağını vurgulamaktadır.

Tyson'a (2020) göre öğrenciler sisteme nitelikli veri üretseler de ihtiyaç duydukları şey sosyal etkileşim olacak ve bu sebeple sisteme olumlu yaklaşmayacaklardır. Dolayısıyla ebeveynlerin öğrenci başarısızlığının nedeni olarak öğretmenle etkileşim eksikliğini dile getirmeleri muhtemeldir. Eğitimin öğretmen öğrenci etkileşimi gerektirdiğini vurgulayan bir diğer araştırmacı olan Schiff (2020), bu etkileşimin öğrenciyi bireysel özellikleri, geçmişi, ailesi ve çevresi gibi genel özellikleriyle tanımak, öğrenciye duygusal yaklaşmak, tepki vermek, öğrenciyi motive etmek, gerektiğinde göz teması ya da fiziksel temas kurmak, ses tonunu ayarlamak gibi durumları içerdiğini belirtmektedir.

Öğretmenlerin benzersiz uzmanlığını ön plana çıkartan Felix (2021), yapay zekanın kültürel değerleri, tarihi ve toplumsal normları öğretemeyeceğini, insan öğretmenin; duruş, ses, jest ve mimikleri ile bir adım önde olduğunu, göz teması kurma, ses tonundaki değişimler, bedenin aktif şekilde kullanımı gibi yetenekleriyle yapay zekanın öğretmenin yerini alamayacağını belirtmektedir.

Yapay zekanın eğitimde öğretmenin yerini almayacağı öğretmene yardımcı konumunda kalacağını belirten Zhao ve Liu (2018) ise, eğitimin özel bir kavram olduğunu; bilgi aktarımı ile öğretimin sağlandığını, karakter geliştirme, bilinmeyeni keşfetme ve yaratıcllığa teşvik etme ile eğitimin gerçekleştiğini ifade etmektedir. Bu bağlamda yapay zekanın öğretimi gerçekleştirebileceği mümkün sayllabilirken eğitimi ise gerçekleştiremeyeceği söylenebilir. 
Öğretmenleri mesleklerinde başarılı kılan; öğrencilere ilham vermek, olumlu sınıf iklimi inşa etmek, sınıftaki çatışmaları çözmek, öğrencilerin bağlılık ve aidiyet oluşturmalarını sağlamak, dünyaya öğrencilerin gözünden bakabilmek, öğrencilere rehberlik ve koçluk yapabilmek gibi özel yeteneklerdir. Yapay zekanın bu özellikleri taklit edemeyeceğini dolayısıyla öğretmeni yerinden etme olasılığının düşük olduğunu belirten Bryant, Heitz, Sanghvi ve Wagle (2020) asistan rolünde olmasının daha faydalı olacağını ve öğretmenin eğitim-öğretime daha fazla vakit ayıracağını belirtmektedir. Bu kapsamda araştırmacılar; öğretmenlerin hazırlık, değerlendirme ve idari görevler nedeniyle eğitim öğretime yeterli zamanı ayıramadıklarını, çalışma zamanlarının yalnızca \% $49^{\prime}$ unda öğrencilerle etkileşim halinde olduklarını tespit etmiştir. Dolayısıyla yapay zekânın öğretmen asistanı rolünde görev almasıyla otomasyon gerektiren ve zaman alan işleri devralacağı, bu sayede öğretmelerin öğrencilerine daha fazla zaman ayırabileceği söylenebilir.

Öğretmenlerin ses, görünüş, bilgelik, disiplin, gibi özellikleri öğrencilerde güven oluşturmaktadır ve öğretmene saygınlık katmaktadır. Dolayısıyla yapay zekânın öğrenci ve velilerin güvenini sağlayabilmesi, bu sistemlerin kullanılmasında ve başarı elde etmesinde en temel noktalardan birini teşkil etmektedir. Bu kapsamda eğitimde yapay zeka sistemlerine olan güveni değerlendiren Qin, Li ve Yan'a (2020) göre kullanıcıları güven konusunda etkileyen faktörler listedeki gibi olup, yapay zeka:

- İşlevsellik açısından bir öğretmenden beklenen görevleri yerine getirebilmesi gerekmektedir ve bu şekilde kullanıcının güven duyması sağlanacaktır.

- Performans geliştirme açısından öğrenciler hakkında veriler toplayarak bireysel öğretim yoluyla öğrenim performanslarını artıracaktır.

- Adil ve tutarlı olma açısından tüm öğrencilere karşı eşit mesafede olacak, cinsiyet, ırk, din ya da çalışkan olma gibi sebeplerle öğrenciler arasında ayrımcılık ya da önyargı benzeri duyguları yaşamayacaktır.

- Görünüm açısından eğitim öğretim işlevini robot görünümü üzerinden gerçekleştirecekse, fiziksel olarak insana benzeyen robotlar sayesinde daha çok güven verecektir. 
- Ses açısından öğrencilerle etkileşime girerken insan sesini andıran ve güven veren bir tonda olması öğrencileri rahatlatacaktır.

- Öğrenci ile etkileşim açısından sosyal ve duygusal yakınlık kurabileceği henüz öngörülmese de sinirlenme gibi olumsuz insani özelliklere sahip olmayacağ için özellikle hata yapmaktan çekinen öğrenciler daha rahat hissedecektir.

- Tekrar açısından müfredat yetiştirme, idari görevleri yerine getirme ve değerlendirme yapma zorunlulukları kişiselleştirilmiş öğretim metodu ile aşılacak, her öğrenciye öğrenene kadar tekrar imkanı verecektir.

Listelenen bu özellikler sayesinde kullanıcıların sisteme olan güveni artacaktır. Ancak yapay zekânın öğretmenin yerini alması durumunda veri güvenliği başta olmak üzere bazı endişeler ortaya çıkacaktır. Schiff'e (2020) göre bu endişelerden bazıları; öğrencileri derinlemesine tanıyan sistemin öğrenciye adeta kendi eğitim kaderini tayin edebilecek kadar esneklik tanıyacak olması, öğretmenin sahip olduğu yaratıcılık ve çeşitlilikten uzak kalarak öğrencileri standardize etmesi, öğrenciyi tüm özellikleri ile tanıyan sistemin öğrenciyi çeşitli yönlerde karar almaya yönlendirmesidir. Yapay zekânın mevcut yetenekleri ve öğrenci hakkında erişebileceği verilerin büyüklügü düşünüldügünde bu endişeler yapay zekanın öğretmen olması yönündeki en büyük engeller olarak karşımıza çıkmaktadır.

\section{Senaryo 2: Okul Yönetimde Yapay Zekâ}

İnsanoğlu geleceğe yönelik tutarlı öngörülerde bulunma, eldeki tüm verileri anlamlı şekilde değerlendirme ve doğru planlama yapma gibi nedenlerle yapay zekâyı yönetim alanına taşımıştır. Henüz tavsiye verici asistan rolünde ya da bir insan denetiminde kullanılmakta olan yönetimde yapay zekâ örneklerini genelden özele doğru incelemek gerekmektedir.

$$
\text { Toplum Şehir Örgüt }
$$

Şekil 1. Genelden Özele Yapay Zekânın Yönetimde Kullanımı 
Çin'de uygulanan yapay zekâ tabanlı Sosyal Kredi Sistemi Toplum yönetimi bağlamında yapay zekânın kullanımına örnek teşkil etmektedir. Sistem toplumsal yönetişimi iyileştirmek, düzensizliği ve sahtekârlığ1 azaltmak için yapay zekâ ile donatılmıştır. Bireylerin ve hareketlerin bir koda sahip olduğu sistemde yapay zekâ tüm araçlarla veri toplamakta, verileri analiz etmekte ve bireylerin hareketlerini puanlayarak ödül ya da ceza ile sonuçlandırmaktadır (Kshetri, 2020, s.16).

Yapay zekânın yönetimi üzerinde çalışılan bir diğer alan ise akıllı şehirler projesidir. Akıllı şehir; internet ve akıllı sistemlerle donatılan akıllı evler, otonom araçlar, otonom güvenlik sistemleri, yapay zekâ tabanlı asistan sistemler gibi şehrin tüm alanına yapay zekânın hâkim olduğu bir projedir (Voda ve Radu, 2018, s.110-112). Dolayısıyla şehir hayatı bir anlamda yapay zekâ ile yönetilmektedir.

Yapay zekânın örgüt yönetiminde kullanımı şehir ve toplum yönetimlerinden daha yaygındır. Fakat gerçek liderin yerini yönetim ve özellikle iletişim anlamında alamadığı için henüz örgüt yönetimlerinde tek söz sahibi olamamıştır (Auvinen vd., 2019, s.1). Mevcut gelişmeler ışı̆̆ında yapay zekânın önümüzdeki yıllarda yöneticilerin yönetim görevlerinde daha fazla rol alacağı bilgi sağlama alanlarında yönetime katkıda bulunacağı öngörülmektedir. Noponen'e göre (2019) yapay zekânın yönetimde kullanımına karşı bakış devrimci ve evrimsel olarak iki ayrı görüşte toplanmaktadır. Devrimci görüş; yöneticiler dâhil birçok mesleğin dönüşüm geçireceğini belirtirken, evrimsel görüş yapay zekânın yöneticilerin becerilerini tamamladığını vurgulamaktadır.

Devrimci görüş açısı ile yapay zekâyı örgütte yönetici olarak düşüneceğimiz için öncelikle yönetimin ne olduğunu anlamak ve yapay zekâdan ne beklediğimizi belirlememiz gerekmektedir. Bu kapsamda yönetici olarak yapay zekâyı, Mintzberg'in belirlediği yöneticinin kişiler arası ilişki, karar verme, bilgi işleme rollerinde avantajları bakımından değerlendirmemiz doğru olacaktır (Mintzberg, 1971, s.97).

Yöneticinin karar verme rolünde yapay zekâ, verileri analiz ederek daha doğru tercihler yapabilecek, fırsatların kaçmasına müsaade etmeyecek, panik, korku, heyecan gibi tepkilerde bulunmayarak olumsuz durumların kararlar üzerinde etki bırakmasına imkân vermeyecek, aynı anda birden fazla karar üzerinde çalışabilecektir (Canbek, 2020, s.177). 
Dolayısıyla insan zekâsının birden çok değişkene ya da tüm verilere dikkat ederek karar veremediği durumlar yapay zekâ yönetiminde yaşanmayacaktır.

Yöneticinin kişiler arası rolünde yapay zekâ, iş başarısı ve çalışanların refah dengesini koruyacak, çalışanlara mobbing uygulamayacak, ayrımcllık yapmayacak, çalışanları daha yakından tanıyacak fakat elde ettiği verileri çalışanlar aleyhine kullanmayacak, etik dışı davranmayacak, performansları nesnel ölçecek, her an ulaşılabilir olacaktır (Canbek, 2020, s.180). Bu bağlamda yönetici personele karşı adil, objektif ve tarafsız olacak, dolayısıyla çalışanların yapay zeka ile daha verimli çalışması sağlanabilecektir.

Yöneticinin bilgi işleme rolünde yapay zekâ, büyük verileri kısa sürede işleyebilecek, birimlere ve çalışanlara anında bilgi iletecektir, personelin bilmesi gereken tüm bilgileri personelden saklamayacak, personelin bilgiye erişiminde sorunlar yaşanmayacaktır (Canbek, 2020, s.182). Bu bağlamda, yapay zekâ yönetiminde çalışmakta olan personel okula ve yönetime ait bilgilere şeffaf bir şekilde erişebilecek ve yönetimde hesap verebilirlik sağlanacaktır.

Evrimsel görüş açısından ise, yapay zekânın yönetimde yardımcı rolünde yer alması durumunda, yöneticinin idari koordinasyon ve kontrol gibi zamanın çoğunu alan görevlerle uğraşmasının önüne geçilecektir. Chernov ve Chernova' göre (2019) yöneticilerin en çok zaman ayırdıkları faaliyetler incelendiğinde \%47 ile koordinasyon, planlama, programlama, raporlama ve kontrol gibi rutin işler ön plana çıkmaktadır.

Dolayısıyla yöneticinin çalışma zamanlarının yarısını rutin gerektiren işlerin kapladığını söylenebilir. Yapay zekâ yöneticinin bu tip işlerini otomatikleştirerek yönetişim ve liderlik becerileri üzerine odaklanmasını kolaylaştıracaktır. Bu sebeple yöneticilerin kendilerine yardımcı rolünde yapay zekâyı kullanmakta bir endişe duymaması, iş kararları verirken yapay zekâ sistemlerinin vereceği tavsiyelere ve raporlamalara güvenmesi beklenmektedir.

Yöneticilerin hangi görevleri yapay zekaya devretmeye hazır olduklarını tespit etmeyi amaçlayan Chernov ve Chernova (2019, s.135) kontrol ve koordinasyon, raporlama, planlama ve organizasyon, veri analizi, kaynak tahsis etme gibi konularda yöneticilerin istekli olduklarını fakat personel gelişimi, koçluk, strateji geliştirme, problem çözme, karar 
verme gibi konularda görev paylaşımı yapmaya hazır olmadıklarını belirtmektedir. $\mathrm{Bu}$ bağlamda yöneticilerin otomasyon gerektiren ve zamanlarının çoğunu alan faaliyetleri daha kesin sonuçlar üretecek yapay zekaya bırakma konusunda endişe etmedikleri fakat insani ilişkiler, karar verme gibi yetenek gerektiren örgüt liderliğini elde tutmaya devam etmek istediklerini söyleyebiliriz. Bu kapsamda günümüz yöneticileri hem başarılı kalmak hem de yerlerini koruyabilmek için deneyim sahibi olmalı, veri analizi yapabilmeli, yaratıcı düşünme ve strateji geliştirme becerilerine sahip olmalıdır (Kolbjornsrud, Amico ve Thomas, 2016). Ayrıca okul yöneticilerinin; karmaşık problem çözme, büyük miktarda veri yönetimi yeteneğine sahip bilişimsel düşünme, yaratıcılık, insan yönetimi, liderlik, iş birliğine dayalı yönetim, düzenleme, motivasyon, değerlendirme, sağlam sonuçlara varma, karar verme, hizmet odaklılık, bilişsel esneklik, becerilerini geliştirmeleri önemli görülmektedir (Moldenhauer ve Londt, 2019, s.58). Bu beceriler aynı zamanda yapay zekânın yönetimde kendi başına yürütebildiği becerilerdir. Günümüz örgüt liderleri bu becerilerini geliştirerek yapay zekâyı kendi kontrolü altında tutmayı başarabilecektir. Bununla birlikte okul yöneticileri öğrenci ve ebeveynlerin teknoloji kullanımına giderek daha aşina olmasını göz önünde bulundurarak kendi önyargılarını arkada bırakıp yenilikçi yapay zekâ teknolojilerini daha fazla okula adapte etmeli ve kendisini yapay zekâ liderliğine hazırlamalıdır (Tyson, 2020, s.75-78).

Yapay zekânın yönetim becerilerinde insan liderlerden üstün olacağ1 düşünülmektedir fakat henüz duygusal zekâ ile donatılmamış ve lider üye alışverişini anlama becerisine sahip olmamaları nedeniyle örgüt üyelerini grubun parçası olduklarını hissettirmeleri noktasında eksik kalacakları düşünülmektedir (Smith ve Green, 2018, s.86). Dolayısıyla liderlerin sert becerileri yapay zeka tarafından gölgede birakılacak, yumuşak becerileri ise günümüz teknolojisi ile yetersiz kalacaktır (Premuzic, Wade ve Jordan, 2018). Buradan hareketle otorite sağlama söz konusu olduğunda insan liderden üstün olması beklenen yapay zekânın, iletişim, anlayış, hoşgörü, iş birliği, liderliğin paylaşımı, kültür oluşturma gibi becerilerde eksik kalacağ 1 ifade edilebilir.

Diğer örgütlerde olduğu gibi eğitim örgütlerinde de liderlik yapay zekâ tarafından devralınmış değildir. Fakat eğitim yöneticilerine okul yönetiminde yardımcı olduğu bilinen yapay zekâ tabanlı okul yönetim 
sistemleri, uygulama ve yazılımları bulunmaktadır. Bu uygulama ve yazılımlar öğrencilerin duygusal takibi ile rehberlik hizmeti sunma, okula ulaşım, okul güvenliği, öğretmenlerin ders programlarını oluşturma, veli bilgilendirme, mali kontrol ve okul yöneticisine tavsiyelerde bulunma gibi alanlarda yardımcı olmaktadır. Bu kapsamda bu sistemlerin okulların çözüm bekleyen sorunlarına da katkı sunması beklenmektedir.

Eğitim örgütlerinde en sık karşılaşılan sorunlardan biri dinamik yeniliğin sağlanamaması ve yeniliğe karşı eğitim paydaşları tarafından direnç gösterilmesidir. Yapay zekâ tabanlı sitemlerin tam bu noktada etkili olabileceği savunulmaktadır. Bu konuda Lynch (2019), "Watson", "Azure Bot", "Amanda", "Nextplay", "Ellen" gibi yapay zeka tabanlı sistemlerin personele koçluk, mentorluk sağlama, işe alımda doğru karar verme, ihtiyaç duyulan dinamiklik ve yenilikçilik fikrine yöneltme, çalışana özel kariyer gelişimi imkanı sunma gibi alanlarda okul yönetimine yardımcı olabileceğini belirtmektedir.

Yapay zekânın okul yöneticilerine yardımcı olacağı bir diğer alan ise öğrencilerin okula bağlıllkları ve okul terki sorunudur. Yapay zekâ bu noktada verilerden yararlanarak erkenden uyarı verebilecek, risklerin belirlenmesinde ve terklerin önlenmesinde yöneticiye yardımcı olacaktır. Okul yöneticilerinin çözmesi gereken diğer konu ise yeteneklerin erkenden tespitidir. Yapay zekâ öğrenciler hakkında detaylı bilgiler depolayarak analiz edebilecek dolayısıyla öğrencilerin uzmanlık alanlarını daha net bir şekilde tespit ederek okul yöneticisini bilgilendirecektir (Lancrin ve Van Der Vlies, 2020, s.10).

Yapay zekâ alanında yapılan başarılı çalışmalar yakın gelecekte yapay zekânın hemen hemen tüm meslekleri insanlı̆̆ın elinden alacağı yönünde endişelere sebep olmaktadır. Bu endişelerin oluştuğu alanlardan biri de eğitimdir. Henüz dijital kişiselleştirilmiş öğretim asistanı ya da sınıf içi uygulamalar şeklinde kendine yer edinen yapay zekânın gelecekte öğretmen ya da okul müdürü görevlerini yerine getirmesi mümkün olabilecektir. Araştırma buradan hareketle endişeleri eğitime aktararak, yapay zekânın öğretmen ve okul müdürü olarak görev aldığ1 senaryolar oluşturmayı ve bu senaryoların olası faydalarını, senaryolar hakkındaki endişeleri ve senaryoların uygulanabilirlik durumlarını ortaya koymayı amaçlamaktadır. 
İlgili alan yazın incelendiğinde yapay zekanın örgüt yöneticisi rolünde ele alınarak tartışıldığı çalışmalar görülmektedir (Canbek, 2020; Lynch, 2019; Lancrin ve van den Vlies, 2020; Premuzic vd., 2018; Smith ve Green, 2018; Tyson, 2020; Noponen, 2019). Ancak, yapay zekânın eğitim örgütlerinde yönetici olarak ele alındığı bir araştırmaya rastlanmamıştır. $\mathrm{Bu}$ bağlamda araştırmanın literatüre katkı sağlaması beklenmektedir. Diğer taraftan ilgili alan yazında yapay zekânın öğretmen olarak görev almasını konu edinen araştırmalar bulunmaktadır (Edwards ve Cheok, 2018; Kolchenko, 2018; Tyson, 2020; Felix, 2021; Zhao ve Liu, 2018; Bryant vd., 2020; Qin vd., 2020; Schiff, 2020). Ancak literatürdeki araştırmaların uzmanlarla görüşme yöntemini tercih etmediği ve birçoğunun yapay zekânın öğretmenin olası faydalarının neler olacağını ortaya koymadıkları gözlenmiştir. Bu bağlamda araştırma yapay zekânın her iki görevinde de olası faydalarını, endişeleri ve uygulanabilirliğini ortaya koyacak olması bakımından önemli görülmektedir. Ayrıca araştırmanın, bulguları itibariyle hem öğretmenleri hem de okul müdürlerini geleceğe hazırlanması ve ayrıca politika belirleyicilere ışı tutması beklenmektedir.

\section{Yöntem}

\section{Araştırma Modeli}

Bu çalışma yapay zekânın gelecekte tüm meslekleri yerine getirmeye başlayacağı endişesini eğitim örgütlerine aktararak ve yapay zekânın sınıf yönetimini ve okul yönetimini devralmasını temel alarak gelecek senaryoları oluşturmak amacıyla yapılmıştır. $\mathrm{Bu}$ amaç doğrultusunda çalışma, nitel araştırma yöntemlerinden hermenötik fenomenoloji deseni ile yürütülmüştür. Nitel araştırma bireylerin veya grupların, sosyal veya insani bir soruna atfettiği anlamı keşfetmeyi ve anlamayı amaçlamaktadır (Creswell, 1998). Durum, tecrübe, olay, alg1, kavramlar fenomen olabilmektedir ve araştırmacı ilgili kişilerin bakış açları ile olayları, durumları, tecrübeleri anlamlandırmaya çalışmaktadır (Groenewald, 2004, s.3-6). Patton'a (2002) göre bu yöntemde olgular manipüle edilmemektedir. Fenomenolojik araştırma bir olgu hakkında daha 
ayrıntılı bilgiye sahip olmamızı sağlayabilecek, örnekler, açılamalar ve yaşantılar ortaya koyabilecek bir desendir (Yıldırım ve Şimşek, 2013).

\section{Çalışma Grubu}

Çalışmada kartopu örnekleme yöntemi kullanılmıştır. Kartopu örnekleme yöntemi ulaşılması ve tanımlanması zor örnekleme gruplarına ulaşmada kullanılmaktadır. Önce çalışma evreninden bir katılımcıya ulaşılmakta ve daha sonrasında ulaşılan katılımcının yönlendirmesiyle diğer katılımcıya ulaşılmakta böylece çalışma grubu oluşturulmaktadır (Böke, 2009). Çalışma konusu hakkında evrende yeterli bilgiye sahip olan ve sorulara gerçek anlamda cevap verebilecek uzmanlara ulaşmanın zorluğu nedeniyle kartopu örnekleme tercih edilmiştir. Bu doğrultuda yapay zeka ve eğitimde yapay zeka kullanımı alanında en fazla bilimsel çalışması bulunan öğretim görevlileri tespit edilmiş, mail yoluyla kendileri ile iletişime geçilmiştir. Maile olumlu dönüş yapan katılımcıdan alanda uzman bir başka katılımcı önermesi istenmiş ve bu şekilde çalışma grubu oluşturulmuştur. Çalışma kapsamında ulaşılan örneklemin konu ile ilgili kapsamlı bilgi ve tecrübeye sahip olduğu varsayılmıştır. Bu kapsamda kartopu örnekleme yoluyla oluşturulan çalışma grubu 7 doktor unvanına sahip, 3 doçent doktor unvanına sahip 10 öğretim görevlisinden oluşmaktadır. Sanders'a (1982) göre fenomenolojik bir araştırmada katılımcı sayısının en az üç olması gerektiği belirtilmekte iken Yıldırım ve Şimşek'e (2016) göre katılımcı sayısı en fazla on olmalıdır. Bu doğrultuda çalışmanın katılımcı sayısı uygunluk göstermektedir.

\section{Veri Toplama Aracı ve Verilerin Toplanması}

Çalışmada veri toplama aracı olarak nitel araştırmalarda sık kullanılmakta olan yarı yapılandırılmış görüşme kullanılmıştır. Yarı yapılandırılmış görüşme önceden hazırlanan sorular eşliğinde ilerlemekle birlikte katılımcıyı cevaplar bağlamında yönlendirmemekte katılımcıya konu ile ilgili olarak belirli düzeyde esneklik sağlamakta ve derinlemesine bilgi edinmeyi amaçlamaktadır (Büyüköztürk, Çakmak, Akgün, Karadeniz ve Demirel, 2018). 
Çalışma kapsamında öncelikle ilgili alan yazın taraması yapılmıştır. Daha sonra alan yazından elde edilen bilgiler doğrultusunda uzman görüşleri alınarak yarı yapılandırılmış görüşmede kullanılacak sorular oluşturulmuştur. Kartopu örnekleme yöntemi ile ulaşılan katılımcılara görüşmeye başlamadan önce, görüşmenin 45-60 dakika süreceği, kimliklerinin gizli kalacağı hakkında bilgi verilmiş, ulaşılan sonuçların sadece bilimsel araştırma için kullanılacağı bildirilmiştir. Görüşmeler, çevrim içi toplantı sağlayıcı uygulamalar vasıtası ile gerçekleştirilmiş ve katılımcıdan izin alınmak suretiyle kayıt altına alınmıştır. Kayıt altına alınan veriler, görüşmeler tamamlandıktan sonra Word kelime işlemci aracılı̆̆ıyla yazıya geçirilmiştir.

\section{Verilerin Çözümlenmesi}

Verilerin çözümlenmesinde betimsel analiz yöntemi kullanılmıştır. Burada amaç elde edilen bulguların düzenlenmesi, yorumlanması ve bir sonuca ulaşılarak çalışmada yer almasıdır (Yıldırım ve Şimşek, 2013). Kayıt altına alınan görüşmeler hiç bir detay atlanmaksızın Word kelime işlemcisine aktarılmıştır. Böylece veriler Word kelime işlemci üzerinde analiz edilmiştir. Elde edilen veriler, açık kodlama yöntemi kullanılarak tek tek analiz edilmiş, ilgili senaryolar kapsamında olası faydalar, endişeler ve uygulanabilirlik şeklinde alt temalara ayrılarak çözümlenmiştir. Verilerin çözümlenmesi esnasında katılımcıların cevapları soru numaralarına göre yanyana getirilmek suretiyle aynı soruya verilen cevaplar birlikte incelenmiştir. Katılımcıların tüm sorulara verdikleri cevaplar bu yöntem ile anliz edilerek çözümlenmiştir. Analiz sonucunda elde edilen bulgular aktarılırken katılımcıların görüşleri "Katılımcı 1 (K1), Katılımcı 2 (K2),." Şeklinde kısaltmalar yapılarak aktarılmıştır.

\section{Bulgular}

Katılımclarla görüşmelerden elde edilen verilerin betimsel analizi sonucunda bulgular 1 tema ve 3 alt tema altında toplanmıştır. Analiz sunucunda elde edilen alt temalar Şekil 2'de verilmiştir. 
Eğitimde YZ Gelecek Senaryoları

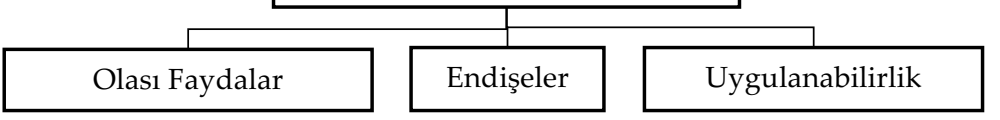

Şekil 2. Eğitimde YZ Gelecek Senaryolarına Ait Tema ve Alt Temalar

Şekil 2'de görüldüğü üzere betimsel analiz sonucunda elde edilen 1 tema altında toplam 3 alt tema bulunmaktadır. Bu alt temalar her iki senaryo için "olası faydalar, endişeler ve uygulanabilirlik" şeklinde belirlenmiştir. Temalara ait kodlamalar belirlenirken açık kodlama yöntemi ve eksensel kodlama yöntemi belirlenmiştir. Strauss ve Corbin'e (1998) göre açık kodlamada veriler ayrı ayrı parçalar halinde yakından incelenerek birbirleriyle benzerlik ve farklılıklarının ortaya konulurken, eksensel kodlama, açık kodlama neticesinde elde edilen kavramlar birbirleriyle karşılaştırılarak daha kapsamlı kavramlar oluşturulmakta, kategoriler arasında bağlantı kurulmaktadır. $\mathrm{Bu}$ doğrultuda görüşmelerden elde edilen veriler satır satır analiz edilerek açık kodlama yapılmış ve burada elde edilen kategoriler arasında bağlantılar kurularak üst kavramlarla ilişkilendirilmiştir.

\section{Senaryo 1'e Ait Alt Temalar}

Olası Faydalar: Katılımcılara yapay zekânın öğretmenin yerini aldığ1 Senaryo 1 aktarılmış, bu senaryonun gerçekleşmesi halinde "Yapay zekânın iletişim, ölçme değerlendirme gibi sınıf yönetimi süreçlerinde nasıl hareket edeceği ve insan öğretmene göre olası faydalarının neler olacağı" sorulmuştur. Tüm katılımcılar tarafından verilen cevaplardan ön plana çıan ve sık tekrarlanan olası fayda "kişiselleştirilmiş öğrenme üzerinden öğrencilerin daha nitelikli öğrenme süreçleri geçirecekleri ve insani olarak yaşanan olumsuz özelliklerin yaşanmayacağg1" olmuştur. Bu konu hakkında katılımcıların görüşleri şu şekildedir:

Bu öğretmen unutkanlık göstermeyecek, etkileşimlerini, deneyimlerini, öğrenci hakkında edindiği tüm bilgileri, önceki yıllardaki öğrenci performansın vb uzun yıllar hafizasında tutabilecektir. Öğrenciyi bireysel takipte, yıl içi performans izlemede başarll olacaktır. Bireysel anlamda tüm öğrencileri tanıyacă̆̆ derse olan ilgileri net tespit ve öğrencileri analiz edebileceği için her 
birine özel teknikler uygulama imkânı ve zamamı doğacaktır. Bir artısı da 7/24 ulaşılabilir ve görev başında olmasıdır. (K8).

Sabırla kızmadan tekrar edebilen, bireysel öğretim yapan ve öğrenci öğrenmeden bir üst seviyeye geçmeyen bir sistemden bahsediyoruz. Öyle bir sistem ki sürekli kendini update ediyor, 20 sene önceki bilgileriyle devam etmeye çalışmıyor. "Öğretmenler yeni teknolojiyi takip etmiyorlar" eleştirisinin son bulmasını da sağlayacak. Etkinlik bitiminde anında dönüt veriyor, sinıf kalabalıktı bu etkinlikleri akşam değerlendireyim vakit yok gibi durumlar söz konusu değil. Anlık aile bildirimi yapryor, sadece akademik anlamda değil, öğrenciyi sözel, duygusal, fiziksel ve ruhsal anlamda analizini takibini yapıyor. Okulda öğretmenler arası ya da yönetici ile günümüzde yaşanan çatışmalar hiçbir şekilde yaşanmıyor. İşine hiç geç kalmıyor, öğrencilere karşı yakınlık-uzaklık hissi duymuyor, başarılı öğrencilere toleransh davranayım gibi durumlar yaşanmıyor (K7).

Bireye ait tüm veriler toplanabilirse ve şu an ki halini geride bırakarak insansı özellikleri artırllırsa sınıf yönetimi geleneksel yönetimden kurtarabilecektir (K3).

Bu sistem öğrencilere özel uygulamalar yapabildiği için derse adapte etmeyi daha etkili yapacak, derslerin en verimli şekilde geçmesini sağlayacaktır. Bu sistem simffta verilecek kararlarda tüm verileri işleme kapasitesine sahip olduğundan etkili kararlar verebilecektir. Öğretmen not değerlendirmesinde hep bir önce okuduğu kâğıdın etkisinde kalır. Şu öğrencinin bu sorudaki cevabına şöyle puan vermiştim burada da şu kadar verebilirim şeklinde hep bir etki altında kalır. Öğretmen sinıf yönetiminde de birçck konuda çeşitli değişkenlerin etkisinde kalır; veliler, öğrenciler, diğer öğretmenler, okul müdürü gibi. Bu sistem gerek sinav değerlendirmelerinde gerek yönetimde bu tarz etkilerde kalmayacaktır. YZ insani dertlerden de muaf olacaktır, yaşam derdi, hastalıklar gibi eğitim öğretim dışında işlerle ilgilenmek durumunda kalmayacaktır (K6).

$\mathrm{Bu}$ sistem sayesinde öğrenciler hemen hemen her konuyu sanal deneyimlerle öğrenme imkânı bulabilirler. Öğrencilerin hepsinin güçlü ve zayıf yönlerini tespit edebilecektir. Öğrenciye özel içerik üretimi sağlayacaktır. Ortalama bir sınıfta ise durum öyle değildir. Başarnlllar ortalar ve zayıflar vardır, öğretmenler genel olarak bu şekilde kategorize eder ve her öğrencinin gerçekten güçlü ve zayıf yönlerini tespit etmek onlar için zordur (K1).

Öğrencinin neyi bilip neyi bilmediğinin tespiti 30 kişilik bir sinufta bile zordur. Fakat YZ tarafindan bu iş etkili ve doğru şekilde yapılır, tam öğrenme sağlanmış olur. Gerekli olan tüm verilere ulaşabilirse ve gerçekten insan zihni 
gibi işler hale getirilmişse öğretmenin çözüm üretemeyeceği alanlarda dahi çözümler sunabilir (K4).

Sistem bazı branşlarda ve öğretmen eksikliği olan bölgelerde uygulanarak ciddi bir açı̆̆ı kapatabilir ve insan öğretmenden daha iyi eğitim yapabilir. Bunun gerçekleşmesi çok uzun zaman almayacaktır (K10).

Bu sistem her gün her bir öğrenciyi ayrı ayrı takip edebilecektir. Öğretmen her öğrenciyi tam tanıyamaz ve her gün detaylı inceleyemez. Arka stralarda oturan bir öğrencinin keyfi yoksa öğretmen bunu fark edemez. Ama YZ tüm ögrencilerdeki duygusal, ruhsal durumları tespit etme becerisine sahip olacaktır ve şu an öğretmenlerin aklına gelmeyen çözümler sunabilecektir. İdeal bir ölçme değerlendirme tespiti varsa $Y Z$ bu ideal ölçme değerlendirmeyi de gerçekleştirecektir. Gerekirse o yıla kadar sorulmuş tüm konuları analiz ederek özgün araçlar oluşturabilir. Daha geçerli ve güvenilir, öğrencilerin öğrenmelerine değerlendirmeler hazırlayabilir. Günümüzde ise genelde konulara üstün körü bakılarak ya da bir yerlerden kopya edilerek hazırlanmaktadır. Bireysel öğretim ve değerlendirmelerle beraber bireysel müfredat da uygulayacaktır. Günümüzde müfredat hayal edilen öğrenci ve toplumu oluşturmak adına tek tip hazırlanmıştır. Tabi YZ'nın bireysel müfredat ve öğretim uygulaması toplumlarda çeşitliliği să̆layacaktır (K2).

Endişeler: Katılımcılara bu senaryonun gerçekleşmesi halinde "Yapay zekâ öğretmen hakkında endişelerin, bilinmezliklerin neler olduğu" sorulmuştur. Katılımcıların "senaryoyu şu an ki yapay zekânın yapabildikleri üzerinden değerlendirdiklerinde insani yönlerin eksik olacă̆ı" yönünde hemfikir olduğu görülmüştür. Katılımcılar görüşlerini şu şekilde ifade etmiştir:

YZ'nın insan etkileşimli işlerde görev alması için henüz erken bir dönemdeyiz. Duygu, sevgi, empati, bă̆glılı gibi alanlarda yapay zekâ henüz gelişmiş değildir (K3).

Ö̆̆rencilere sözü geçecek mi? Ö̆ğrenciler onunla dalga geçer mi? Böyle durumlarda nasıl tepki verir? Öğrenciler bu sisteme güvenebilir mi, ne kadar sürede alışır? Bu sistem öğrencilere hangi şekilde yaklaşacak, ekranlar üzerinden mi yoksa fiziksel bir görünüme bürünmüş robotlar üzerinden mi? Hangisi daha etkili olacak? Fiziksel bir görünümde olursa bir öğretmen gibi hareket edebilecek mi? Insan daha önce görmediği sorunlarla karşılaştığında yeteneğini yaratıcılı̆̆ın devreye sokarak çözümler üretebilir. Peki, YZ böyle durumlarda ne tepki verecektir? (K7). 
Öğretmenlik motomot bilgi alışverişi değildir, psikolojik, pedagojik açıları bulunur. Öğrenciye yakınlık önemlidir. Öğrenciye ne kadar yakın olabilecek, sinıfta kültürel farklılıklar varsa ya da özel gereksinimli öğrenciler varsa nasıl hareket edebilecek bilmiyoruz? Diyelim ki öğrenci kopya çekti. Bu durumda öğrencinin bir üst seviyeye geçtiğini sanan $Y Z$ nasıl davranacak? Ailevi bilgilere de erişim sağladı, peki mahremiyet nerede? Gizlilik sağlanabilecek mi? Devamsızlık yapma ihtimalini tespit etti analizleri sağlam, peki devamsızlık ve okul terki olduğunda müdahalesi olabilecek mi? Öğrenci ödevini yapmadı ama ailevi, maddi sebepleri var. YZ'ya bunu aktardığında nasıl hareket edecek, anlayış gösterme yetkisi olacak mı? Kendisine nitelikli veri sağlayan sınıftaki öğrencilere yönelir mi? (K8)

YZ öğretmen öğrencilere tam hâkim olmak adına onlarla ilgili tüm verileri toplayacaktır. Hal, Hareket, davranış, duygu, düşünce, ailevi durumlar, să̆lık durumu vb. Acaba eğitim amaçl bir örgütte bu kadar verinin tek elden toplanması uygun mudur? Veriler nerede depolanır, kimin erişimi vardır gibi endişeler olacaktır tabi. (K4).

Bir soru sorsak muhtemelen aynı kişi bile beş farklı cevap verecektir. İnsan hep aynı durumda ayn tepkiyi vermez ve kurallara göre davranmaz. Yeri geldiğinde kural dışı davranır ya da her günkü davranışı ayn değildir. $Y Z$ ise günümüzde kendine belirlenen programa göre kurallara göre hareket eder, kural dışına çıkmak gereken zamanda bile çıkmayacaktır. Beklenmedik durumla karşılaşıldığında YZ nasıl hareket edecektir? Öğretmen öğrencileriyle sadece eğitim öğretim yapmaz, dertlerini dinler, duygularına, sevinçlerine, üzüntülerine ortak olur. YZ olabilir mi? (K5).

Makineler ya da sistemlerin insani özellikleri henüz yoktur. İletişim ve etkileşim kurmada yetersizdir. Eğitimde ise en önemli şey iletişim ve etkileşimdir. En önemli kısmından yoksun kalmış oluyoruz bu durumda. Ayrıca bu etkileşim ve iletişimle birlikte; anaokulu öğrencisinden üniversite öğrencisine kadar birçok öğrenci öğretmenini rol model almaktadır. Öğretmenine saygı duyar, üstün görür hareket, davranış, giyinişi ile rol model alır. Peki, ben YZ öğretmen gibi olacă̆ım diyen olabilir mi? Bu durumda kültürü, dini, tarihi kim hangi ruh ile anlatacaktır? (K6).

Öğretmenler bir dönemde birçck sımıfa derse girerler ya da sinıfa birçok öğrenci gelir. YZ sınıfı tamamen tanıdı bir gün öğrenciler ya da sinıf değişmek zorunda kaldl, bocalayacak mı? YZ ilişki ve etkileşim kurmada eksiktir, bununla beraber sınıfta öğrenciler arası etkileşim ve iletişimi sosyal ağlar insan kadar 
anlaml şekilde yorumlayamayacaktır. Insan kendi kararları üzerinde muhasebe yapabilme yetisine sahiptir fakat şu an için $Y Z$ değildir. Sistem bir karar verdiğinde neye göre verdiğini tam olarak verebilecek miyiz? Şu an veriler üzerinde hareket eden $Y Z$ öğretmene yeterli veri üretilemediğinde verimli olacak mı? Peki ya öğrenciler $Y Z^{\prime}$ yı kandırmaya yönelik veriler üretirse, yanlış kararlar almasina sebep olabilir mi? (K2).

Burada önemli konulardan birisi öğrencilerin sistemi öğretmen yerine koyabilmesi ve ona güven duyması, ondan öğrenmeye meraklı olmasıdır. Ĕger bu sistemin sınıfa kurulu olduğunu düşünüyorsak ve fiziksel anlamda varliğı olacaksa insansı özelliklerinin gelişmiş olması faydalı olabilir. Görünüm, hareket etme gibi. Ayrica bu sistemlerin fonksiyonel olarak ve bilgi aktarımı konusunda belki de insandan daha iyi olacaklarna şüphe yoktur ama sadece fonksiyonel olmak öğretmenlik için yeterli midir? (K9).

Uygulanabilirlik: Katılımclara "Senaryo 1'in uygulanabilirliği" hakkındaki görüşleri sorulmuştur. Katılımcılar yapay zekânın şu an ki yeteneklerinin sınırlı olduğu ve öğretmenlik yapmaya hazır olmadığı ancak ve ancak yeterli gelişimi gösterebilirse ve denemek suretiyle uygulanabileceği görüşündedir. Bununla birlikte yeterli gelişimi sağlasa bile sınıfta öğretmenin tüm işlerine yardımcı olmasının daha etkili olacağı vurgulanmaktadır. Katılımcıların bu konudaki görüşleri şu şekildedir:

Yapay zekâ öğretmenin yapamayacă̆ı birçok şeyi yapabilir, takip edebilir, analiz edebilir, sinıfin tamamına odaklanabilir, geleceğe yönelik tahminlerde bulunabilir, öğrencileri duygusal ruhsal fiziksel yönden takip edebilir, ölçme değerlendirme süreçlerinde öğretmenden hızlı ve doğru değerlendirme yapabilir. Öğretmenin yapması, hazırlaması gereken bir sürü evrak vardır. Hatta genelde bu ne gereksiz iş, ne kadar da vaktimi aldı gibi cümleler duyarı. Yapay zekâ bunlarn hepsinde öğretmenden daha iyi davranabilir. Fakat bilincin olmamasi, etkileşim, iletişim eksikliği ve psikolojik temelden dolayı bir öğretmenin yerini tutamayacaktır. Dolayısıyla yapay zekânın da avantajlarından yararlanmak ama sınıfta insani etkileşimi de să̆lamak için yapay zeka öğretmenin asistanı konumunda olmalıdır (K7).

Standart olaylar dışında bir olay olduğunda, yani YZ eğitimsiz olduğu bir durumla karşılaştığ̊ durumda nasıl karar verecek, verdiği kararlar güvenilir olmayacaktır, karar verirken düşünme danışma süreçleri olmayacaktır (K2). 
Evet yapay zeka bir sürü avantaj barındırıyor ama öğrencilere koçluk, rehberlik yapabilecek birisi lazım, ayrica ses, görüntü gibi sinıfta her şeyin kontrol edildiği bir ortamda öğrenci ne kadar hareket imkanı bulur, dört duvardan farkı kalır mi, nihayetinde insana her zaman ihtiyaç bulunur, sinıf yönetimi tüm yönleriyle insan elinde kalmaya devam etmelidir (K3).

$Y Z$ tamamen sinifin tüm süreçlerini işletemez. Asistan öğretmen olarak kullanılmasının daha faydalı olacağı görüşündeyim. Sınıfı tamamen idare edemez mi? Eder tabi ama bununda tüm süreç boyunca ya da uzun süre olamayacağın düşünüyorum. Ancak şöyle uygulanabilir, uçaklardaki oto pilot gibi. Nasıl ki belirli durumlarda kullanilıyor o şekilde olabilir. Örneğin öğretmen derse giremedi çeşitli sebeplerden, sistem öğretmen olmasa da bir iki dersi kendisi götürebilir. Öğrencilere bireysel ödevler verir, onlara ayrı ayrı dönüt uygular gibi. Böylece insanın sinıftaki varlığı iptal edilmemiş olur. Öğretmeni sadece öğretim yapan olarak düşünmemek lazım. Öğrenci dertleriyle ilgilenen, her türlü durumda onlara psikolojik destek sağlayan, duygusal, ruhsal açıdan sağlıklı kalmalarını sağlayan yönleri de vardır. Örneğin okullarda rehber öğretmenler vardır. Peki, öğretmenleri makineye çevirdiğimizde bu destekleri sağlayacak bir öğretmene yine de ihtiyacımı olmayacak mı? (K8).

Yapay zekânın en zor çalıştı̆̆ı alan insandır. Nesnelerle, birbirleriyle iletişim kurabilir etkileşimde bulunabilir ama insanla iletişim ve etkileşim sadece konuşmakla biten bir süreç değildir. Konu anlatır, denetim yapar, analiz çıkartır ama insani özellikleri zayıftır. $Y Z$ ancak kendi verileriyle hareket edecektir. Dolayısıyla insanın önemi bir kez daha ortaya çıkar, asistan olması daha mantıklıdır. Tabi bu tahminleri hep bilinmeyene yönelik şimdiki yetenekleri üzerinden yapıyoruz (K4).

Öğrenci devamsızlık yaptı, bu konuda insan gibi müdahale edebilecek mi? Sebebini çözmek için insan aile ziyareti yapıyor yeri gelince ama bunlar YZ ile olmayacak. Dolayısiyla insani müdahaleler gerektiren kısımlarda insana ihtiyacımız vardır. Sinıfta tüm süreçlerde YZ'nın etkin olması ama öğretmenin varlığının devam ettirmesi sayesinde öğretmenlerin kendilerini eğitim öğretimden alıkoyan işlerle uğraşması diye bir durum söz konusu olmayacak kendilerini eğitim öğretime tamamen adayabilecekler. Bence iyi ve başarılı olarak nitelendirdiğimiz öğretmenleri etkilemeycektir, eğitim öğretimde yetersiz kalan öğretmenlerin yerini alması daha muhtemeldir (K1).

İnsanın bir öngörüsü vardır. Öğrencinin gözlerine bakarak bir şeyleri anlayabilir, tahmin edebilir, bir işi başarı başaramayacă̆ın anlayabilir. YZ 
bunu yapamaz. Burada sorun eğitimi YZ'nın tek başına yönetip yönetemeyeceği ve yönlendirip yönlendirmeyeceğidir. Dolayısıyla insan denetimine ihtiyaç bulunmaktadir (K5).

Sistemin oluşturulması için her okul ve sinıfin donanımsal olarak yeterli seviyede olması gereklidir. Dolayısıyla bazı ülkeler ya da bazı bölgeler arası eşitsizlikler meydana gelebilir. Ayruca burada devletlerin ciddi anlamda bütçe ayırmaların gerektirebilir. Diğger taraftan diğer mesleklerden farklı olarak öğretmenlik standart olmayı kabul etmeyen ve ekstra özellikler ile sürekli gelişim gerektiren bir meslektir. Bu anlamda ĕgitim penceresinden bakıldı̆̆ında mesleki yeterlilikleri gösteremeyen öğretmenlerin yerini alması daha hızı gerçekleşecektir. İlk etapta birkaç sene boyunca sinıfin doğrudan sisteme bırakılmayacağını öğretmenle birlikte ilerleyeceğini düşünüyorum. Dolayısıyla geçiş aşamasında asistan rolünde kalması daha uygun olabilir (K10).

Ben her şeye rağmen bu senaryonun uzak olmadiğını ve imkânsız olmadiğımı düşünüyorum. Birincisi eskiden imkânsız dediğimiz her şey şu an mümkün. Ikincisi halihazırda YZ' ya insansı özellikler kazandırmak için çalışmalar yapıldığın biliyoruz. Belki üniversite sinavı bile olmayacak YZ'nın tüm eğitim döneminde gösterdiği performansa göre hareket edilecek, hatta daha ileri gidelim okulların olmadı̆̆ı senaryolar bile olabilir (K6).

Pandemi ile beraber okullar kapand, eğitimler durdu. Öğretmenler uzaktan eğitimler gerçekleştiriyorlar fakat hepimiz biliyoruz ki bu eğitimler yetersiz kalıyor ve öğrenciler $Y Z$ tabanlı eğitim uygulamalarnna yöneldi, tüm öğrenciler neredeyse dijital okuryazar oldu. 10 yılda gerçekleşecek gelişmeler bir yılda gerçekleşti. Şimdi bu perspektiften baktı̆̆ımızda bence hazırbulunuşluğu tam olan bir sistemin öğretmenin yerini almasına hiç olmadığı kadar yakınız. Dönüşüm çok uzak değil ve zor olmayacak (K9).

\section{Senaryo 2'ye Ait Alt Temalar}

Olası Faydalar: Katılımcılara yapay zekânın okul yönetiminde müdürün yerini aldığı Senaryo 2 aktarılmış, bu senaryonun gerçekleşmesi halinde "Yapay zekânın iletişim, yönetsel süreçler, denetim, mali durum, güvenlik gibi okul yönetimi süreçlerinde nasıl hareket edeceği ve günümüze göre olası faydalarının neler olacağı" sorulmuştur. Verilen cevaplar incelendiğinde "okulun güvenliği, disiplin sağlanması, bürokratik süreçlerin hızla işlenmesi, tüm okula hâkim olması, her an 
okulun her noktası hakkında bilgi sahibi olması, nesnel performans değerlendirmesi gerçekleştirmesi" gibi birçok alanda fayda sağlaması beklenmektedir. Katılımcılar görüşlerini şu şekilde ifade etmişlerdir:

Günümüz yöneticilerinin insani özelliklerinden dolayı bazı öğretmenlerle daha yakın ilişkiler kurduğunu görebiliyoruz. Dolayısıyla performans değerlendirmeler ya kâğıt üstünde bırakılıyor ya da yanlı gerçekleştiriliyor. YZ bu noktada öğretmen performanslarını gerçekçi şekilde değerlendirecek, kimseye yakınlık uzaklık duymayacaktır. Yönetimde adil olacaktır, iletişimde tüm öğretmenleri zamanında ve doğru bilgilendirecektir. Okulla ilgili tüm verilere sahip olacağ̆ için geleceğge yönelik mantıklı ve gerçekçi tahminlerde bulunacaktır, dolayısıyla karar alma, okulun stratejik planlarm, vizyonunu belirlemede daha etkili olacaktır (K7).

YZ kural neyse kuralına göre yönetecektir. Yıllarca aynı bireylerle çalışsa bile şaşmayacaktır. Günümüzde klasik yöneticilerin halen var olduğu ve tek amaçlarının var olan durumu devam ettirmek olduğunu biliyoruz. Geliştirme, üretme, yenilik söz konusu olduğunda klasik yöneticilerin önüne geçeceğini ön görmemiz mümkündür. Personelin gelişim göstermesi gereken durumlarm net tespiti ve gelişimlerinin sağlanmasında etkili olacaktır. Hatta öğretmenlere özel içerik üretecektir. Okul planlarını yaparken insanın dikkate almadığ faktörleri hesaba katabilecektir. Örneğin öğrencilerin hangi dönemlerde daha başarılı olduğu hangi dönemlerde ne yapılması gerektiği gibi konularda şu an hesaba katılmayan birçok faktörü hesaba katabilecektir. (K2).

Kaynaklarm doğru zamanda doğru alanlara aktarılması, gereksiz harcamalarm önüne geçilmesi, rutin ve tekrarl işlerin yerine getirilmesinin gerektiği tüm durumlarda etkili olacaktır (K3).

Sadece öğretmen değil, öğrenci ve aileler ile ilgi tüm verilere erişecek ve bu verileri analiz edecektir. Bu bağlamda çok değişkenli analizler yaparak tıpk bilimsel bir çalışma gibi sonuçlar ortaya koyacaktır. Topladığı tüm verilerin depolanması, hızla bu verilere ulaşılması, karşılaştırılması, geleceğe yönelik öngörüde bulunulması açılarından faydası olacă̆ı kesindir. Bu sayede zamandan, kırtasiye işlerinden tasarruf sağlayacaktır. Bu veriler ayrıca politika belirleyicilerin elinde olacaktır. Ülkedeki tüm öğrencilere ve eğitim sistemine hâkim olma açısından ve somut adımlar verilere dayalı kararlar alınması açısından etkili olacaktır (K8).

Okulun güçlü ve zayıf yanlarını tüm verileri değerlendirerek ortaya konmada etkili olacağı için gelecek hedeflerinde daha başarılı olacaktır. Bütçede kayıp varsa 
tespiti, gelecekteki durumlar için hangi alana ne kadar harcama yapılması gerektiğinin net tespitinde etkili olacaktır (K4).

Bir müdür okulda o an kaç kişi olduğunu, hangi öğretmenin nerede olduğunu, hangi öğrencinin ne yaptı̆̆ını bilemez. Örneğin istenmeyen bir durum oldu. $O$ an kim nerede bilecek, nasıl hareket edilmesi ve planın hıla uygulanmasinda etkili olacaktır. Okul güvenliğinde de yine aynı şekilde ilgili ilgisiz kişilerin tespiti olası güvenlik aksaklıklarının öngörülmesi gibi süreçleri ve okulu kontrol etme becerisi insandan çok daha üst düzeyde olacaktır. Günümüzde okullarda disiplin sorunları mevcuttur, YZ yönetiminde de olması muhtemeldir. Fakat sistem bazı mahrumiyetler getirmek suretiyle disiplini yerleştirebilir tıpkı bir ülkede pilot çalışması yapılan sosyal yönetim olduğu gibi (K6).

Endişeler: Katılımcılara bu senaryonun gerçekleşmesi halinde "Yapay zekânın yönetiminde ne gibi bilinmezliklerin bizi beklediğini ve bu konuda endişelenmemiz gereken alanların neler olduğu" sorusu yöneltilmiştir. Katılımcılarının görüşlerine göre okulu disipline etme, yönetim süreçlerinin etkililiği, güvenlik, geleceğe yönelik öngörü ve etkili planlama gibi noktalarda faydalarının olmasına rağmen insan ilişkilerinin bu denli yoğun olduğu eğitim örgütlerinde "liderliğin" eksikliği konusunda endişelerin ön planda olduğu belirlenmiştir. Katılımcıların bu kod hakkındaki düşünceleri şöyledir:

Okul yönetimi sadece güvenlik, denetim, disiplin, değildir. Okul her şeyden önce insanla iletişim gerektirir. Tüm insanlarn yönetmek liderlik becerileri gerektirir. Çeşitli liderlik stilleri olduğunu biliyoruz peki YZ hangi liderlik stilini tercih edecektir? Bu tercihi yönetimde etkili olacak mıdır? (K7).

Okulun güvenliğini ya da disiplinini sağlamada öğrencileri fişleme gibi bir durum söz konusu olur mu? Sistemin okuldaki etiketleri öğrencileri gerçek hayata atıldıkları zaman nasıl etkileyecek? Bence insan bu sistemlere müdahale etmeden duramaz "insan yapısı değil mi bu bizi dinleyecek tabi ki" diyebilir. Siyasi, bireysel ya da tanıdıkları için ya da her hangi bir sebeple sistemin kararların manipüle etmeye çalışabilir. (K6).

Ĕger eğitildiği durumlar üzerinden hareket ediyorsa okulda o güne kadar karşılaşılmadiğı durumlarda nasıl davranacak? Okula öğretmen alımını da sistem yapıyorsa nasıl kararlar verecek, başarılı olabilecek mi? Örneğin çok iyi bir insan, çok iyi bir öğretmendir ama mezun olduğu üniversite yeterince saygın değildir, insan bu durumları anlayabilir ama YZ nasıl karar verecektir? (K5). 
Sistemin vereceği kararlar bir denetimden geçmeyecekse, verilen kararlarm sorumluluğu kimde olacak. Örneğgin günümüzde insanlar birbirlerini mahkemeye verebiliyorlar. Okulda yaşanan aksi bir durumda hukuksal bağlamda kim sorumlu olacak? (K10).

Veliler bu sisteme itiraz edip veri güvenliği konuların gündeme getirebilirler. Ama unutmamak gerekir $k i$ şu an gençler zaten tüm varliklarıla tüm verilerini sosyal medyadan paylaşmaktalar. Yine de bu tepki anlaşılabilir bir tepkidir, okulda öğrenci, ögretmen ve aileler ile ilgili tüm veriler olacaktır ve bu veriler çeşitli mihraplara geçme tehlikesi içerisinde olabilir (K4).

Öğrenciler ve öğretmenler bazen çözümleyemedikleri durumları okul idarecisine iletir, sorunlarına çözüm isterler. Peki, şu durumda çözüm istenecek merci neresidir? Sorunlar nasıl iletilecektir? İstendiğinde nasıl çözüm sunacaktır? Ayrıca toplanan tüm bilgilerin içinde mahrem bilgiler de olacaktır, ayrıca okulda biri bizi gözetliyor gibi bir durum için gizlilik gerçekten önemlidir (K8).

Okulun birer dijital yönetimli hapishane ortamına dönüşmesi kaçınılmazdır (K3).

Bunca verinin depolanması mümkün müdür? Okullar bunları sağlayabilecek mi? Devletler bu maliyeti karşılamaya niyetli mi? Güvenlik konusunda günümüzde uygulanan sistemlerde yanlış kararlar ya da önyargılı kararlar verdiğini okuyoruz. Dolayısıyla okul güvenliği ya da yönetiminde bu tarz durumlarla karşılaşılabilir mi? Sistemi yanlış verilerle aldatmak, yanlış kararlar vermesine neden olmak mümkün olur mu? (K2).

Uygulanabilirlik: Katılımcılara "Endişeler ve bilinmezlikler ışı̆̆ında Senaryo 2'in uygulanabilirliği" hakkındaki görüşleri sorulmuştur. Katılımclar genel olarak, yönetici olmanın öğretmenliğe göre daha fazla idari, bürokratik ve tekrarlı işleri barındırmasından dolayı yapay zekânın böyle bir senaryo ile okullarda yer alabileceğine daha fazla olasılık tanımaktadırlar. Fakat insani ve liderlik boyutunun eksik kalmasından dolayı bu sistemin ancak insan denetimi altında faaliyet gösterirse okullarda anlamlı hale geleceği görüşünü belirtmişlerdir. Katılımcılar bu konuda şu şekilde düşünmektedir:

Okullarda rutin dışı işler ve insani ilişkilerde yaşanacak aksaklıklardan ötürü örgütün merkezinde insan olması gereklidir (K3). 
Sistem tüm veriler ışı̆̆ında analiz yapacaktır ve bu okulların daha sağlam adımlarla yürütülmesini kolaylaştıracaktır fakat diyelim ki iki kez hata yapmış bir öğretmene üçüncü bir şans tanıması mümkün müdür? Kararları aldığında doğruluğunu kim teyit edecektir? Dolayısiyla vereceği kararlar tavsiye niteliğinde olmalıdır. Diğer taraftan günümüzde okul yöneticilerinde hangi özellikleri arıyoruz? Sınıfın içinden gelen, sınıfı bilen, belli bir süre öğretmenlik deneyimi olan, mümkünse yüksek lisans ve doktora yapmış gibi kriterler arıyoruz değil mi? Diyelim ki lisansüstü seviyesi zaten YZ'da var bilgisel anlamda peki ya diğerleri, tecrübe, sinıf deneyimi, öğretmenin halinden anlama durumu? (K8).

Yönetim sınf öğretmenliğ $i$ gibi değildir daha ziyade bürokratik işler ve evrak işlerle uğraştırarak müdürün eğitimsel faaliyetlerle, okulla, öğrencilerle ilgilenmesine engel olur. Bu durumda YZ'nın yetenekleri ile insanın eğitim liderliğini birleştirmek etkili bir sistem doğuracaktır (K4).

Herkes makineden emir almak istemeyebilir. Bu durumda nasıl hareket edilecek? Örneğin finans sisteminde makinelerin yönettiği durumlar var ama eğitim örgütlerinde insanlar bu kadar güven duyacaklar mı? Düşünün herkes sürücüsüz arabada gitmek istiyor ama herkes kontrolü ona bırakıp uzunca bir süre yolculuk yapmaktan endişe duyuyor (K10).

Öğretmen olan senaryoya göre yönetici olması daha uygulanabilir bir senaryodur çünkü maliyet açısından daha mümkün gözükmektedir. Fakat başta eğitimin tüm süreçleriyle makineye bırakılması olmak üzere birçok endişe bulunmaktadır. YZ'nın da sağlayacă̆ı avantajları göz ardı etmeden insana yardımcı rolünde kullanılması mümkündür. Üstelik bu sayede sürekli idari işlerle uğraşmak zorunda kalan yönetici kendisini ĕ̆itim öğretim süreçlerine de adayabilecek, daha başarulı sonuçlar alınabilecektir (K1).

Okulu daha disiplinli, daha ekonomik yönetmesi, sürdürülebilirliği sağlaması, öğretmen performanslarm net değgerlendirmesi ve mesleki gelişimlerinin doğru yönde gerçekleştirmesi yönlerinden avantaj să̆layacă̆ $ı$ kesindir. Fakat okullarda iki tür işlem vardır. Evrak işleri, rutin işler ve insani, sosyal ilişkiler. YZ'nın şu an ki yetenekleri insani ilişkilerde zayıf olduğ u için direk yönetime geçebileceğini söylemek zordur. Bunun yerine müdür yardımcısı pozisyonunda görev alması daha kolay olacaktır (K9).

Okul sadece kendi içinde kapalı bir kurum değildir. Çevreyle ve birçok kurumla ilişkiler kurup geliştirmesi gerekir. Ayrıca öğrencilerle iletişim ve etkileşim, öğretmenlerin motivasyonu gibi konularda etki sağlaması gerekir. Bu 
gibi durumlarm gerçekleştirilebilmesi için insana, lidere ihtiyaç devam edecektir (K7).

Okullarda olumlu kültür ve iklim oluşturmak çok önemlidir. Sistem tek başına bunu sağlayamayacaktır. Diğer taraftan yapılacak analizler, okulun her anın bilme ve müdahale etme imkanı, akıllı ve gerçekçi öngörüler gibi avantajları göz ardr etmeden sistemin eğitime aktarılmasının en iyi yolu asistan rolünde olmasıdır (K5).

İlk defa karşılaşılmış durumlarda insanın yaratıcılı̆̆ına, ferasetine ve liderliğine ihtiyaç vardır. Böyle durumlarda $Y Z$ tarafindan verilecek kararların denetlenmesi gerekecektir. Dolayısıyla $Y Z^{\prime}$ 'dan gelen kararlar tavsiye niteliğinde olmalıdir (K2).

\section{Sonuç}

$\mathrm{Bu}$ araştırma, insan hayatındaki yerini hızla genişleten ve gelecekte birçok mesleği yerinden etmesi beklenen yapay zekânın eğitimde de "öğretmen" ve "okul müdürü" olarak görev aldığı senaryoların uygulanabilirliğini, günümüz öğretmen ve okul yöneticisinden farkının ne olacağını, bu senaryolarla birlikte ortaya çıacak endişelerin ve bilinmezliklerin neler olduğunu ortaya koymak amacıyla yapılmıştır. Bu bağlamda yapay zekanın öğretmen olduğu Senaryo 1 ve okul müdürü olduğu Senaryo 2 oluşturulmuştur. Senaryolar bağlamında katılımcılarla görüşme yapılmış ve veriler analiz edilerek bulgulara ulaşılmıştır.

Senaryo 1'in bulgularına göre yapay zekânın öğretmen olması durumunda; insani olarak yaşanan unutma, kızma, sabırsızlık, yönetici ile çatışma yaşama, gibi olumsuz durumlar yaşamayacak, sınıfa tam hâkimiyet kuracak, öğrencileri tüm özellikleriyle tanyacak, kişiselleştirilmiş öğretim, bireysel takip ve rehberlik yapacak, bireysel müfredat uygulayacak, öğrencileri yıl boyu izleyecek ve nesnel değerlendirmeler yapacak, paydaşlar tarafından her an ulaşılabilir olacaktır. Değişim ve yenilikler konusunda sürekli güncel kalacak, bireysel ve nesnel değerlendirme yapacaktır. Araştırmanın bu bulguları Ahmad vd. (2020), Chen vd. (2020), Osetsky vd. (2020), Taneri (2020) tarafından da desteklenmektedir. Bu senaryo kapsamında ulaşılan yapay zekânın bazı branşlarda yaşanan öğretmen eksikliğini giderebileceği bulgusu aynı zamanda Edwards ve Cheok (2018) tarafından da 
desteklenmektedir. Diğer taraftan yapay zekânın öğretmenlik mesleğini devralması senaryosu için tespit edilen endişelerin bazıları; veri güvenliği, psikolojik ve pedagojik yaklaşım, görünümü ve güven sağlayıp sağlayamayacağı, öğrencilerin ihtiyaç duyduğu rol modeli karşılayıp karşılayamayacağı ve tarih, din, kültür gibi değerlerin öğrencilere öğretilmesi, benimsetilmesi noktalarında yetersiz kalacak olması şeklindedir. Bu endişelerle birlikte araştırmanın Senaryo 1'in uygulanabilirliği bağlaminda en önemli bulgusu; "yapay zekâ öğretmenlerin yerini alamayacaktır". Katılımcıların büyük çoğunluğu yapay zekânın günümüzdeki mevcut yetenekleri ile sınıfta tek başına öğretmenin yerini alamayacağı, sınıf yönetiminin her anını destekleyen bir asistan olmasının ise eğitimi çok daha ilerilere taşıyacağı görüşünü savunmaktadır. Katılımcılara göre yapay zekanın öğretmenin yerini alamayacak olmasının sebeplerinden bazıları; duygu, empati eksikliği, öğrencilerde motivasyon ve güven duygularının harekete geçirilememesi, psikolojik ve pedagojik bağlamlardan yoksun olması, veri güvenliği endişesi ve sahte verilerle aldatılabilme ihtimali, öğrencilerle iletişim ve etkileşim eksikliğidir. Araştırmanın "Yapay zekâ öğretmenin yerini alamayacak" yönündeki bulgusu Felix (2021), Kolchenko (2018), Li ve Yan (2020), Schiff (2020) tarafından yapılan araştırmalarla benzerlik göstermektedir. Hem katılımcı görüşleri hem de ilgili araştırmalar yapay zekânın öğretmenle bütünleşik şekilde, sinıftaki tüm süreçlerde kullanılması ve asistan görevi üstlenmesinin sınıf yönetiminde daha etkili olacağına işaret etmektedir (Bryant vd., 2020; Zhao ve Lui, 2018). Bu sayede yapay zekâ tüm sınıfın bireysel, anlık ve nesnel bir şekilde takip edilerek değerlendirilmesine, rutin ve idari görevlerin yerine getirilmesiyle öğretmenin asıl mesleği olan eğitim öğretime odaklanmasına katkı sağlayacaktır. Aynı zamanda öğretmen devreden çıkartılmayarak sınıfta öğrenci öğretmen iletişim ve etkileşimi devam etmiş olacaktır.

Senaryo 2'nin bulgularına göre yapay zekâ okul yönetiminde, okul güvenliği, öğretmen performansı ve gelişimi, tüm verileri dikkate alarak somut planlar yapılması, öğretmenlere eşit mesafede olunması, mobbing kurulmaması, kaynakların doğru zamanda doğru yerlere gereği kadar harcanması, güçlü ve zayıf yönlerin net tespiti, fırsatların kaçırılmaması, tehditlerin önceden fark edilmesi, disiplinli yönetim, anında veli 
bildirimleri yapma gibi birçok noktada günümüz okul yöneticilerinden daha etkili olacaktır. Yapay zekânın insani ilişkiler, bilgi işleme ve karar verme konularında Canbek (2020), araştırma bulgularımızla benzer sonuçlara değinmektedir. Bununla birlikte bu senaryoda, insan ve çevre ile iletişim, beklenmedik durumlarda verilecek kararlar, verilerin güvenliği ve manipüle edilmesi, okullarda örgüt kültürünün ve ikliminin oluşturulması noktasında lidere duyulan ihtiyaç, sürekli izleme ve sıkıyönetimin getireceği hapishane havası oluşturma ihtimali gibi yönlerden endişe duyulmakta ve okul yönetiminde tek başına yetkilendirilmesi uygun görülmemektedir. Bunun yerine okul yöneticisine yardımcı asistan rolünde görev alması daha faydalı görülmektedir. Bulgular arasında en dikkat çeken nokta yapay zekânın tek başına yönetimde olması durumunda yumuşak liderlik becerilerinin eksik olacağı yönündedir. Dolayısıyla sert liderlik becerilerinin daha ön planda olacağı ve liderlik yöntemlerinin öğretmen performansını etkilediği (Özgenel ve Aktaş, 2020) birlikte ele alındığında, yumuşak liderlik becerilerinde yetersiz kalacağ 1 (Premuzic vd., 2018) söylenebilir.

Dolayısıyla yönetici bağlamında yeterli gelişimi gösterememiş yapay zekanın öğretmen performanslarını olumsuz yönde etkileyeceği düşünülebilir. Liderlik becerilerinden biri de örgütlerde olumlu kültür oluşturulması ve çalışanların örgüte bağlılığının sağlanmasıdır. Benzer şekilde yapay zekânın lider üye etkileşiminde yetersiz kalacak olması (Smith ve Green, 2018), okullarda öğretmen bağlılığ1 gibi olguları tartışmalı hale getirecektir. Senaryo 2'nin diğer bir bulgusuna göre yapay zekânın yeteneklerinden yararlanırken aynı zamanda insanın liderlik becerilerini de kaybetmemek gerekmektedir ve bunun için yapay zekânın okul müdürüne asistan olması, tavsiyeler sunması daha faydalı olacaktır. Bu sayede okulun tüm verilerini analiz ederek tavsiyelerde bulunacak, etkili planlamalar yapılmasını sağlayacak ve daha önemlisi liderin, neredeyse zamanının yarısını alan rutin ve bürokratik işlerden kurtularak (Chernov ve Chernova, 2019), eğitim öğretim ve insan ilişkileri için daha fazla zaman ayırmasını sağlayacaktır. Bu senaryodan ortaya çıan bir diğer bulgu ise okul müdürünün yerini alamasa da okul müdür yardımcısının yerini alabilecek olmasıdır. Rutin, tekrarlı, bürokratik işleri yapmak konusunda mahir olan yapay zekâ müdür yardımcısı rolünde daha anlamlı bulunmuştur. 
Araştırmadan elde edilen bulgular ışığında, yapay zekânın günümüzde sahip olduğu yetenekler itibariyle öğretmen olarak sınıf yönetimini ya da okul müdürü olarak okul yönetimini devralması mümkün gözükmemektedir. Ancak yeterli gelişimi göstermesi neticesinde görev alması muhtemeldir. Yapay zekânın eğitime katacağı avantajlar ve endişeler birlikte ele alındığında her iki senaryo için de asistan rolünde yer alması ve her iki senaryoda da kontrolün insanda olması önerilmektedir. Bununla birlikte insani özellikler açısından gelişimini tamamlamış bir yapay zekânın, öğretmen ve okul müdürünün yerini almaya aday olduğunu belirtmek gerekmektedir. Bu sebeple öğretmenlerin eğitim öğretim becerileri, güncel ve teknolojik bilgileri, yapay zekanın ve faydalarının anlaşılması, eğitime entegre edilmesi gibi konularda kendilerini geliştirmeleri, geleceğe hazırlıklı olmaları önemlidir. Diğer taraftan okul müdürlerinin ise liderlik becerilerini geliştirmekle beraber yapay zekanın okulun tüm süreçlerine entegre edilmesi ile ilgili farkındalıklarını artırmaları bu konuda kendilerini geleceğe hazırlamaları gerekmektedir. Bu kapsamda politika yapıcıların geleceğin eğitiminde yapay zekanın edineceği yeni görevlere şimdiden hazırlanması önerilebilir. Ayıca devletler bu konuda kapsamlı politikalar düzenlemelidir. Diğer taraftan gelecek araştırmalar için sınıf yönetimi ve okul yönetimi bağlamında yapay zekâ asistanlığı alanlarında araştırma yapılması önerilebilir. 
EXTENDED ABSTRACT

\title{
Artificial Intelligence and Future Scenarios in Education
}

\author{
* \\ Münevver Çetin - Abdussamet Aktaş \\ Marmara University
}

Artificial intelligence is an information technology that can perceive human cognition, interpret, comprehend, make sense, generalize, make inferences, learn, successfully perform more than one task at the same time (Gondal, 2018, p.1), and in a sense imitate human intelligence. Today, artificial intelligence is used in almost every aspect of our lives such as communication, realization of business and transactions in digital environment, finding location, accessing information quickly, entertainment, storage, banking, finance, social media, health and security (Komalavalli, et al., 2020, p.90 -91). As a result of its development, artificial intelligence, which came to the scene with the ability to distinguish, has now come to direct our lives through its features such as perception, selflearning, decision-making and inference. In the near future, it is expected that artificial intelligence will facilitate the life of humanity by undertaking many tasks and will play a greater role in daily life than humans.

This situation raises some concerns; Some of these concerns are the fate of the data that artificial intelligence will collect, who has access to this data, what kind of actions will be taken on the collected data, artificial intelligence getting out of control, increasing loss of people in wars, and unemployment. Today, the most discussed and worried issue is that artificial intelligence can take the place of people in all professions. From this point of view, the research focuses on the concern that artificial intelligence can replace teachers and school principals in the education sector.

The integration of artificial intelligence into education remains low compared to other sectors. The use of robots for language teaching, personalized teaching assistants, smart school management applications are examples of artificial intelligence supported education applications 
used today. On the other hand, giving grades and evaluation, student absenteeism and dropout prediction, student performance prediction, sentiment analysis, suggestion systems, smart education systems, classroom monitoring, smart school, school supervision and analysis systems are still areas of study (Ahmad et al., 2020, p.8; Chen et al., 2020, p.75272). In the near future, developments such as the placement of voice and face recognition systems in the classroom and school, the creation of educational profiles through individual assessments, 3D and hologram learning environments, the inclusion of VR technology in education, and the employment of artificial intelligence instead of teachers are waiting for us (Taneri, 2020, p.6). In this direction, it is possible to expect artificial intelligence to show itself more in classroom management and school management.

The research aims to reveal possible prospective scenarios of education in the future by considering the point and usage areas of artificial intelligence today. In this context, two scenarios were created, namely artificial intelligence in classroom management and artificial intelligence in school management.

In the classroom management scenario (Scenario 1), the teaching profession leaves its place to artificial intelligence, as predicted for other professions. In this scenario; the possible benefits of artificial intelligence in classroom management, which requires skills such as relations with students and parents, assessment and evaluation practices, student absenteeism, curriculum and lesson plan preparation, the concerns that will arise within the scenario and the feasibility of the scenario were questioned. In the school management scenario (Scenario 2), artificial intelligence will take the place of the school principal and take charge in the school management. In this scenario; on the basis of school management skills such as school safety, academic success, financial management, communication with parents and teachers; the difference of artificial intelligence from today's administrators, its possible benefits, the concerns that will arise within the scenario and the feasibility of the scenario have been questioned. In addition, within the framework of the scenarios, it was discussed whether artificial intelligence could replace the teacher or the school principal, and its possible position in the classroom and school management was tried to be determined. 
The study was carried out with the hermeneutic phenomenology pattern, which is one of the qualitative research methods, as it aims to create future scenarios based on artificial intelligence taking over classroom management and school management in the future. Snowball sampling was preferred in the formation of the study group due to the difficulty of reaching experts who have sufficient knowledge about the subject in the universe and who can answer the questions in real terms. In this direction, the study group consists of 10 lecturers with 7 of whom have doctorate titles and 3 have associate professor titles. It is assumed that the sample reached has extensive knowledge and experience on the subject. In the study, semi-structured interview, which is frequently used in qualitative research, was used as a data collection tool. Descriptive analysis method was used to analyze the data obtained as a result of the interviews.

According to the findings, some of the advantages of Scenario 1 are; avoidance of humane negativities, full dominance of the classroom, getting to know the students with all their characteristics, personalized teaching, individual follow-up and guidance, objective evaluation, accessibility by stakeholders at all times, and being constantly up-to-date on changes and innovations. Some of the concerns raised under Scenario 1 have been determined to be data security, psychological and pedagogical approach, physical appearance and the problem of trust on stakeholders, whether students can meet the role model they need, if s/he will be insufficient in terms of transferring and adopting values such as history, religion and culture to students.

When the findings are evaluated in line with scenario 2, it has been determined that artificial intelligence would be more effective than school managers in many aspects such as school safety, teacher performance and development, concrete planning in the direction of data, equal distance towards teachers, being fair and not applying mobbing, spending the right amount of resources in the right place at the right time, clear determination of strengths and weaknesses, not missing opportunities, noticing threats beforehand, disciplined management, and making immediate parent notifications. However, in this scenario, there is concern about aspects such as communication with people and the environment, decisions to be made in unexpected situations, the security and 
manipulation of data, the need for a leader to create the organizational culture and climate in schools, the possibility of constant monitoring and the possibility of a prison atmosphere brought on by martial law and single authorization is not considered appropriate in school management.

Considering the possible benefits and concerns of both scenarios in line with the findings obtained from the research, it would be more advantageous to be the assistant of the teacher in the classroom and the assistant principal in the school administration, with the abilities of artificial intelligence today. In line with the same findings, it is suggested that the control should be in human in both scenarios. Therefore, it does not seem possible for artificial intelligence to take over the classroom management as a teacher or the school management as a school principal due to the abilities it has today. However, it has been found that an artificial intelligence that has shown sufficient development and has completed its development in terms of human characteristics is a candidate to replace the teacher and school principal. Based on the findings, it is important for teachers to keep their education and training skills and technological knowledge up-to-date, to improve themselves on issues such as artificial intelligence and its benefits, developments in artificial intelligence, integrating artificial intelligence into education, and thus be prepared for the future. On the other hand, school principals need to improve their leadership skills and increase their awareness of the integration of artificial intelligence into all processes of the school and prepare themselves for the future in this regard. In this context, it can be suggested that policy makers should be prepared for the new tasks that artificial intelligence will acquire in the education of the future, and that artificial intelligence-based systems and applications should be disseminated in education as soon as possible. In addition, states should regulate comprehensive policies on the integration of artificial intelligence into education.

\section{Kaynakça / References}

Ahmad, K., Iqbal, W., Hassan, A., Qadir, J., Benhaddou, D., Ayyash, M. and Fuqaha, A. (2020). Articial intelligence in education: A panoramic review. 1-51. doi:10.35542/osf.io/zvu2n 
Aşçı, B. (2017). Olasılık yönetimi: Senaryo analizi. 21.YY'da Eğitim ve Toplum, 6(17), 375-394.

Auvinen, T., Sajasalo, P., Sintonen, T., Pekkala, K., Takala, T. and Luoma-aho, V. (2019). Evolution of strategy narration and leadership work in the digital era. Leadership, 15(2), 205-225. doi:10.1177/1742715019826426.

Böke, K. (2009). Örnekleme. K. Böke (Der.). Sosyal bilimlerde araştırma yöntemleri içinde (s.105-147). İstanbul: Alfa Basım Yayım Dağıtım.

Boucher, P. (2019). How artificial intelligence works. EPRS. Panel for the Future of Science and Technology. 1 Kasım 2020 tarihinde http://www.europarl.europa.eu/RegData/etudes/BRIE/2019/634420/E PRS BRI(2019)634420 EN.pdf adresinden erişildi.

Bryant, J., Heitz, C., Sanghvi, S. and Wagle, D. (2020). How artificial intelligence will impact $\mathrm{K}-12$ teachers. 20 Ocak 2021 tarihinde https://www.mckinsey.com/industries/public-and-social-sector/ourinsights/how-artificial-intelligence-will-impact-k-12-teachers adresinden erişildi.

Büyüköztürk, Ş., Çakmak, E. K., Akgün, Ö. E., Karadeniz, Ş. ve Demirel, F. (2018). Bilimsel araştırma yöntemleri. Ankara: Pegem Akademi.

Canbek, M. (2020). Artificial intelligence leadership: İmitating mintzberg's managerial roles. A. Ö. Tunç ve P. Aslan (Der.), Business management and communication perspectives in industry 4.0. içinde (s.173-187) doi:10.4018/978-1-5225-9416-1.ch010

Chandra, R. (2015). Classroom management for effective teaching. International Journal of Education and Psychological Research (IJEPR), 4(4), 13-15.

Chen, L., Chen, P. and Lin, Z. (2020). Artificial intelligence in education: A review. IEEE Access, 8, 75264 - 75278. doi:10.1109/ACCESS.2020.2988510

Chernov, A. and Chernova, V. (2019). Artificial intelligence in managemnet: Challenges and opportunities. 38th International Scientific Conference on Economic and Social Development, 133-140.

Creswell, J. W. (1998). Qualitative, quantitative and mixed methods approaches. Thousand Oaks: SAGE.

Edwards, B. I. and Cheok, A. D: (2018). Why not robot teachers: Artificial intelligence for addressing teacher shortage. Applied Artificial Intelligence, 32(4), 345-360. doi:10.1080/08839514.2018.1464286

Ertel, W. (2011). Introduction to artificial intelligence. London: Springer. 
Fast, E. and Horvitz, E. (2020). Long-term trends in the public perception of artificial intelligence. Proceedings of the AAAI Conference on Artificial Intelligence, 31(1), 1-7.

Felix, C. V. (2021). The role of the teacher and AI in education. Sengupta, E., Blessinger, P. and Makhanya, M.S. (Der.). International perspectives on the role of technology in humanizing higher education (Innovations in higher education teaching and learning, 33), içinde (s.33-48). Emerald Publishing Limited. doi:10.1108/S2055-364120200000033003

Goel, A. K. ve Polepeddi, L. (2016). Jill Watson: A virtual teaching assistant for online education. 1 Ocak 2021 tarihinde http://hdl.handle.net/1853/59104 adresinden erişildi.

Gondal, K. M. (2018). Artificial intelligence and educational leadership. Annals of King Edward Medical University, 24(4), 1-2.

Grawemeyer, B., Mavrikis, M., Holmes, W., Santos, S. G., Wiedmann, M. and Rummel, N. (2017). Affective learning: Improving engagement and enhancing learning with affect-aware feedback. User Modeling and UserAdapted Interaction, 27, 119-158. doi:10.1007/s11257-017-9188-z

Groenewald, T. (2004). A phenomenological research design illustrated. International Journal of Qualitative Methods, 3(1), 42-55. doi:10.1177/160940690400300104

$\mathrm{Hu}, \mathrm{Z}$. (2020). Influence of introducing artificial intelligence on autonomous learning in vocational education. Jemal, H. A., Kim-Kwang, R. C., Zheng, X. ve Mohammed A. (Der.), AISC 1244. içinde (s.361-366). Springer doi:10.1007/978-3-030-53980-1_54

Huang, Q. ve Shi, L. (2020). Education management reform of private colleges and universities based on artificial intelligence. Jemal, H. A., KimKwang, R. C., Zheng, X. and Mohammed A. (Der.), 2020 International conference on applications and techniques in cyber intelligence. AISC 1244. İçinde (s.334-340). Springer. doi:10.1007/978-3-030-53980-1_50

Kolbjornsrud, V., Amico, R. and Thomas, R. J. (2016). How artificial intelligence will redefine management. Harvard Business Review, 2, 1-6.

Kolchenko, V. (2018). Can modern AI replace teachers? Not so fast! Artificial intelligence and adaptive learning: Personalized education in the AI age. HAPS Educator, 22(3), 249- 252. doi:10.21692/haps.2018.032 
Komalavalli, K., Hemalatha, R. and Dhanalakshmi, S. (2020). A survey of artificial intelligence in smart phones and its applications among the students of higher education in and around Chennai City. Shanlax International Journal of Education, 8(3), 89-95. doi:10.34293/education.v8i3.2379

Kshetri, N. (2020). China's social credit system: data, algorithms and $\begin{array}{llll}\text { implications. IT } & \text { IT }\end{array}$ doi:10.1109/MITP.2019.2935662.

Lancrin, S. V. and Van Der Vlies, R. (2020). Trustworthy artificial intelligence (AI) in education: Promises and challenges. OECD Education Working Papers, 6, 1-17. doi:10.1787/a6c90fa9-en

Luo, S. (2019). Research on the change of educational management in the era of artificial intelligence. 12th International Conference on Intelligent Computation Technology and Automation (ICICTA). doi:10.1109/ICICTA49267.2019.00101

Lynch, M. (2019). Will AI take over educatıonal leadershıp? 10 Aralık 2020 tarihinde https://www.thetechedvocate.org/will-ai-take-overeducational-leadership/adresinden erişildi.

Mathew, A., Arul, A. and Sivakumari, S. (2020). Deep learning techniques: An overview. Abdoul, E. H., roheet, B., ve Ashraf, D. (Der.). International Conference on Advanced machine learning technologies and applications. Içinde (s.599-608) Singapure: Springer. doi:10.1007/978-981-15-3383$9+54$

MEB. (2020). EBA Akullı Destek Sistemi. 1 Kasım 2020 tarihinde https://www.meb.gov.tr/1-milyona-yakin-ogrenci-eba-akademikdestek-sistemi-ile-universite-hedefine-ilerliyor/haber/20798/tr adresinden erişildi.

Mintzberg, H. (1971). Magagerial work: Analysis from observation. Management Science, 18(2), 97-110. doi:10.1287/mnsc.18.2.B97

Moldenhauer, L. and Londt, C. (2019). Leadership, artificial intelligence and the need to redefine future skills development. Journal of Leadership, Accountability and Ethics, 16(1), 155-160. doi:10.33423/jlae.v16i1.1363

Noponen, N. (2019). Impact of artificial intelligence on management. Electronic Journal of Business Ethics and Organization Studies, 24(2), 43-50.

Obschonka, M. and Audretsch, D. B. (2020). Artificial intelligence and big data entrepreneurship: A new era has begun. Small Business Economics, 55, 529-539. doi:10.1007/s11187-019-00202-4 
Oliveira, M., Lopes, C., Soares, F., Pinheiro, G. and Guimaraes, P. (2020). What can we expect from the future? The impact of artificial intelligence on society. 15th Iberian Conference on Information Systems and Technologies (CISTI), 1-6. doi:10.23919/CISTI49556.2020.9140903

Osetskyi, V., Vitrenko, A., Tatomyr, I., Bilan, S. and Hirnyk, Y. (2020). Artificial intelligence application in education: Financial implicatıons and prospects. Financial and Credit Activity: Problems of Theory and Practice, 2(33), 574-584. doi:10.18371/fcaptp.v2i33.207246

Özgenel, M. ve Aktaş, A. (2020). Okul müdürlerinin liderlik stillerinin öğretmen performansına etkisi. Uluslararası Liderlik Çalışmaları Dergisi: Kuram ve Uygulama, 3(2), 1-18.

Patton, M. Q. (2002). Qualitative research \& Evaluation methods. (3rdEdition). Thousands Oaks: SAGE.

Premuzic, T. C., Wadei M. and Jordan, J. (2018). As AI makes more decisions, the nature of leadership will change. Harvard Business Review 1, 2-7.

Qin, F., Li, K. ve Yan, J. (2020). Understanding user trust in artificial intelligencebased educational systems: Evidence from China. British Journal of Educational Technology, 51(5), 1693-1710. doi:10.1111/bjet.12994

Russell, S. J. ve Norvig, P. (1995). Artificial intelligence: A modern approach. New Jersey: Prentice Hall.

Sanders, P. (1982). Phenomenology: A new way of viewing organizational research. Academy of Management Review, 7(3), 353-360.

Schiff, D. (2020). Out of the laboratory and into the classroom: The future of artificial intelligence in education. $A I$ and Society. Springer. doi:10.1007/s00146-020-01033-8

Singh, G., Mishra, A. and Sagar, D. (2013). An overwiew of artificial intelligence. SBIT Journal of Sciences and Technology, 2(1), 1-4.

Smith, A. M. and Green, M. (2018). Artificial intelligence and the role of leadership. Journal of Leadership Studies, 12(3), 1-4. doi:10.1002/jls.21605

Strauss, A. ve Corbin, J. (1998). Basics of qualitative research: Techniques and procedures for developing grounded theory. Thousand Oaks: SAGE.

Taneri, G. U. (2020). Artificial intelligence \& Higher education: Towards customized teaching and learning, and skills for an AI world of work. Research \& Occasional Paper Series: CSHE 6.2020. Center for Studies in Higher Education. 
Teng, X. (2019). Discussion about artificial intelligence's advantages and disadvantages compete with natural intelligence. Journal of Physics: Conf. Series 1187, 1-7. doi:10.1088/1742-6596/1187/3/032083

Türk Dil Kurumu. (2020). 30 Ekim 2020 tarihinde https://sozluk.gov.tr/ adresinden erişildi.

Tyson, M. (2020). Educational leadership in the age of artificial intelligence. (Published Phd Thesis). 1 Ocak 2021 tarihinde https://scholarworks.gsu.edu/eps diss/228/adresinden erişildi.

U.S. Department of Education. (2013). High School Mathematics intervention report: Carnegie Learning Curricula and Cognitive Tutor. 1 Ocak 2021 tarihinde https://files.eric.ed.gov/fulltext/ED539061.pdf adresinden erişildi.

Voda, A. I. and Radu, L. D. (2018). Artificial intelligence and the future of smart cities. Broad Research in Artificial Intelligence and Neuroscience, 9(2), 110127.

Wieringen, F., Sellin, B. and Schmidt, G. (2003). Future education: learning the future, scenarios and strategies in Europe. Luxemburg: CEDEFOP.

Yeoman, I., Andrade, A., Leguma, E., Wolf, N., Ezra, P., Tan, R. and Beattie, U. M. (2015). 2050: New Zealand's sustainable future. Journal of Tourism Futures, 1(2), 117-130. doi:10.1108/JTF-12-2014-0003

Yıldırım, A. ve Şimşek, H. (2013). Nitel Araştırma Yöntemleri. Ankara: Seçkin Yayıncilik.

Yıldırım, A. ve Şimşek, H. (2016). Sosyal bilimlerde nitel araştırma yöntemleri. Ankara: Seçkin Yayıncılık.

Zanetti, M., Rendina, S., Piceci, L. and Cassase, F. P. (2020). Potential risks of artificial intelligence in education. Form@re - Open Journal Per La Formazione in Rete, 20(1), 368-378. doi: 10.13128/form-8113

Zhao, S., Chen, S., Li, W., Li, D., Liu, Z. and Chen, J. (2020). The development of artificial intelligence education resources under the background of the internet of things. 2020 Chinese Control and Decision Conference (CCDC 2020). doi:10.1109/CCDC49329.2020.9164663

Zhao, Y. and Liu, G. (2018). How do teachers face educational changes in artificial intelligence era. Advances in Social Science, Education and Humanities Research (ASSEHR), 300, 47-50. 


\section{Kaynakça Bilgisi / Citation Information}

Çetin, M. ve Aktaş, A. (2021). Yapay zeka ve eğitimde gelecek senaryoları. OPUS-Uluslararası Toplum Araştırmaları Dergisi, 18(Eğitim Bilimleri Özel Sayıs1), 4225-4268. DOI: 10.26466/opus.911444. 